\title{
Syntheticising Scandinavia: The Introduction of Synthetic Pesticides to Scandinavian Gardens, 1945-1952
}

\author{
May-Brith Ohman Nielsen \\ University of Agder, Norway \\ may-brith.o.nielsen@uia.no
}

\begin{abstract}
This study examines the introduction of prescriptive pesticide technologies into Scandinavian family gardens. It analyses pesticide propaganda and plant protection experts' advice and instructions on the use of pesticides directed at amateur, home gardeners in Norway, Sweden and Denmark in the years between 1945 and 1952, the period when the new generation of synthetic pesticides was introduced in Scandinavia, and eagerly advocated by the leading experts of plant protection science. The sources investigated are gardening magazines and their special issues on garden instruction and the use of chemicals through the seasons, edited, published and distributed to a wide readership by national gardening associations. The study shows how the gardening associations in Scandinavia and their popular gardening magazines were major pushers of extensive pesticide spraying practices, with supporting epistemic logic, onto the numerous family gardeners of Scandinavia. Through these gardening associations both the state plant protection authorities and their scientific expertise and also the pesticide companies reached wide groups of citizens, across diverse professions, occupations and ways of life. This served to normalise the use of powerful poisons in small gardens and small-scale food production.
\end{abstract}

Keywords: Synthetic pesticides; pesticide promotion; gardening; gardening associations; knowledge transfer; DDT; entomology; poison

\footnotetext{
${ }^{1}$ This paper is part of "Before the Silent Spring: Pesticides in Twentieth-Century Europe," ed. José Ramón Bertomeu-Sánchez, Special issue, HoST - Journal of History of Science and Technology 13, no. 1 (2019), https://content.sciendo.com/view/journals/host/13/1/host.13.issue-1.xml. It is being published in this issue (14.1) because due to unforeseen circumstances it could not be published last year.
} 
Technology is not simply tools or systems of tools, but the very "way we do things around here." 2 A prominent example of the appropriateness of this broad definition is the field of pesticide technologies, even more so when we seek to track their introduction into the everyday life of significant groups in society. Pesticide technologies are also an exemplary field in which to observe the distinction between prescriptive and holistic technologies, ${ }^{3}$ especially in arenas where scientific expert advisors and state authorities interact with eager and ambitious amateurs. Gardening and gardening organisations form one such arena.

The first phase of wide introduction and mass spread of synthetic pesticides in the Western world took place in the years 1945-1952. In this period a large number of synthetic pesticides were introduced in agriculture, forestry, horticulture, parks and public space management, in the sanitation of houses, living quarters, shops, factories, institutions, food processing factories, food storage, warehouses, boats, fishing equipment, textiles, and clothes among others. These new substances, first and foremost DDT, were also applied on a wide scale to the bodies and beds of people with poor housing and hygiene conditions, such as soldiers, sailors, prisoners, deportees, refugees and children in post-war orphanages. ${ }^{4}$ Some of these pesticides were marketed as multi-purpose remedies, products that consumers could apply to solve problems or improve hygiene and comfort in different areas of their daily lives and surroundings. The later infamous Pestoy DDT, a commercial from 1946, hammered out the slogan "Let's put it everywhere!" to create new demand and new markets for their products. One of these new arenas for adoption of a range of new pesticides was the home garden or family garden. Through family gardens, prescriptive pesticide technologies were brought into the everyday consciousness of substantial numbers of citizens. This promoted a culture of acceptance of toxins even far beyond the realm of agriculture.

Pesticides were by no means unknown in pre-war Scandinavian family gardens. The wartime food situation, although limiting supplies of some imported pesticides, does appear to have widened the use of domestically produced pesticides in many smaller, self-sufficient family

\footnotetext{
${ }^{2}$ Ursula Franklin, The Real World of Technology, rev. ed. (Toronto: Anansi, 1999), 11-12.

${ }^{3}$ Ibid., 18-20.

${ }^{4}$ José Ramón Bertomeu-Sánchez, "Introduction. Pesticides: Past and Present," HoST - Journal of History of Science and Technology 13, no. 1 (2019): 1-27; Robert van den Bosch, The Pesticide Conspiracy (Berkeley: University of California Press, 1989); May-Brith Ohman Nielsen, "Kverk krekene! Strategier for å selge liv og død til norske hageeiere 1945-1975," in Å selge liv og død. Kommersielle strategier og kulturuttrykk i markedsføringen av død og dødsfrykt, ed. May-Brith Ohman Nielsen, 12-45 (Joensuu:University Press of Eastern Finland, 2014); David Kinkela, DDT and the American Century. Global Health, Environmental Politics and the Pesticide that Changed the World (Chapel Hill: The University of North Carolina Press, 2011); Graham A. Matthews, A History of Pesticides (Boston: Cabi, 2018); Fredrick Rowe Davis, Banned - A History of Pesticides and the Science of Toxicology (New Haven: Yale University Press, 2014); Michelle Mart, Pesticides, a Love Story - America's Enduring Embrace of Dangerous Chemicals (Lawrence: University Press of Kansas, 2015); Rob Nixon, Slow Violence and the Environmentalism of the Poor (Cambridge: Harvard University Press, 2011).
} 
gardens. Scarcity of food, especially in Norway, made many families try to grow more food in their home garden or in rented plots or allotments. At the same time farmers and professional gardeners were ordered by the authorities to expand their production of plant-based food. This provided more critical conditions for the spread of plant diseases and plant pests. In a situation where the production of food was of the highest priority at all levels, any technology that might support this purpose was perceived as either essential to protect health, or as part of the patriotic war effort, or perhaps both. Peacetime cost-benefit calculations in these matters were in 1940-1945 widely replaced by wartime cost-benefit rationality. ${ }^{5}$ This contributed to a shift in mind-sets and gardening methods among many gardeners in the years before the new pesticides were introduced in the post-war years.

From the summer of 1945, numerous home gardening families in Norway, Sweden and Denmark were subject to extensive expert instruction and massive commercial propaganda campaigns that urged them to change their methods of gardening and adopt a prescriptive systematic year-round precautionary scheme of procedures for pesticide spraying in their gardens. The main organisational arenas for these campaigns were the gardening associations, and their main mode of communication to their members, sympathisers and gardeners alike, was popular gardening magazines. These magazines instructed family gardeners to carry out their "conscientious," "responsible" and "modern" gardening and maintenance of their outdoor property with the "necessary" chemical weapons against the "enemies of the gardens." These weapons were a combination of various new synthetic chemicals and several older remedies that became widespread among professional gardeners and fruit growers in the 1930s and brought pesticide technologies into peoples' lives.

The gardening organisations pushed and fortified the knowledge, methods, procedures and mind-sets of people regarding post-war pesticide technologies onto and among broad segments of Scandinavian societies and made pesticide technologies "the way we do things around here." ${ }^{6}$ In the years between 1945 and 1952, but also for decades before and after, gardening magazines were among the most widely distributed publications in Norway, Sweden and Denmark because garden associations were among the largest voluntary organisations in these countries. Socially, culturally and demographically, gardening was, and still is, a very widespread activity. Because cultivating gardens is undertaken almost everywhere, the garden associations were exceptional in their broad membership base. They encompassed men and women of all ages, and across different life stages and generations all over these countries, from different backgrounds and socio-economic situations, and with different professional identities and political inclinations. The group of interested sympathisers and readers of

\footnotetext{
5 May-Brith Ohman Nielsen, Små paradiser - Hager gjennom et århundre (Kristiansand: Portal Akademisk, 2015), 123.

${ }^{6}$ Franklin, Real World, 11-12.
} 
gardening magazines was even wider. ${ }^{7}$ These pesticide technologies were prescriptive: they introduced procedures that shifted substantial sections of decision making and control away from the holistic considerations and competence that historically were among the core social, cultural, educational and practical ideals of the popular garden movement, and away from the gardeners and their families and over to the considerations and values of experts. To some extent this caused alienation between gardeners and their own gardens, and patronclient-like relationships with regards to gardening knowledge and practices between plant science authorities and gardeners. The movement brought numerous poisonous chemicals and procedures into the spaces where gardening families were traditionally meant to develop their own experience and judgement, and to learn and exercise their holistic take on gardening and their insights into the processes of life. ${ }^{8}$

Pesticide promotion and instructions and advice on how to use chemicals to protect plants were overwhelming and on the rise in Scandinavian garden associations and their magazines between 1945 and 1952. From 1951 onwards, elaborate seasonal spray plans for small gardens were published regularly together with spraying instructions for each month of the year and warnings not to neglect any of the necessary pesticide sprayings. ${ }^{9}$ These instructions were backed by elaborate organisational efforts, both at the national and local level, to assist and urge the members of local garden clubs, and often their urban or suburban neighbours as well, to comply with these prescriptive technologies and to carry out the spray plans. ${ }^{10}$ In this way the gardening associations and their wide-reaching magazines, which were the major source of gardening information in Scandinavia, became the major arena for the introduction and normalisation of pesticide technologies among the general population. Their messages reached wide groups of citizens, across most professions, occupations and ways of life, and through them, their family members.

This organisational basis for pesticide technologies is of historical importance because these magazines, owned by membership organisations, were significant historical agents in the field of commercial and family gardening. The organised amateur gardeners of Scandinavia were voters, consumers, educators, neighbourhood carers and trendsetters. A significant amount of the garden chemicals distributed in Scandinavia was administered by them, and the harmful effects would be felt by them too. As these magazines were the main source of information and identity formation for amateur gardeners, the knowledge, norms and attitudes that the plant protection experts and magazine editorials promoted must have had a significant impact on the general social acceptance of synthetic chemicals in gardening, and thus probably on the

${ }^{7}$ Ibid., 13-24, 143-151, 156-161, 181-193, 206-214.

${ }^{8}$ Ibid.

${ }^{9}$ In Norway this already started in 1946 . See below.

${ }^{10}$ See below. 
acceptance of poisonous substances in other areas of society and everyday life as well.

The research questions pursued in this article are the following:

1. How were the technologies of the new synthetic pesticides introduced to Scandinavian family home gardeners, and what were the garden authorities' expert advice and instructions on which substances and products to use in the garden, and when and how to apply them?

2. What forms of knowledge on the issue of pesticide technologies and their scientific basis were conveyed to this broad public through gardening magazines?

3. What cultural ideas and figures of thought were constructed in this communication about pesticides directed at the home gardeners of Scandinavia?

4. What similarities and differences can be observed between the editorial and expert positions on pesticides in the gardening magazines of Norway, Sweden and Denmark, and what may have been the possible impact of different editorial and expert policies on the use of pesticide technologies among family gardeners?

New volumes of these magazines were sent out to all the members of the associations six (Sweden) to eight (Denmark, Norway) times a year. Non-members could also subscribe to gardening magazines and receive issues in their letterbox. Many schools of a certain size, teacher training institutions, public park managers, departments and last but not least, public libraries, subscribed to and offered gardening magazines as a main source of accessible gardening information to their students, teachers, staff and visitors. The magazines were also sold through newspaper and magazine kiosks and bookshops. Thus they became the main source of subject knowledge on gardening and gardening technology for Scandinavian gardeners, and the main arena for the transfer of knowledge between subject experts in plant protection science, on the sending side, and professional and amateur gardeners at the receiving end. The magazines were also the main arena for commercial advertisements for pesticides, fungicides and herbicides directed at the same wide audience. Thus they played an essential role in constructing "the way we do things around here." 11

\section{Family Gardens as Markets for Pesticide Technologies}

The history of the expansion of the pesticide technologies and the massive application of pesticides and herbicides within agriculture in the decades following World War II, and of their dramatic and tragic effects on the environment, although not yet exhaustively studied and sufficiently comprehended, is known. ${ }^{12}$ So too is the story of how the most harmful of these

${ }^{11}$ Franklin, Real World.

12 Rowe Davis, Banned. Bertomeu-Sánchez, "Introduction." 
environmental poisons, among them DDT, Parathion and Lindan, were banned or restricted to specific areas of use in most Western countries from around 1970 onwards. The adoption of these chemicals within agriculture and forestry has been examined in historical studies. ${ }^{13}$ Far less research has been carried out on how these harmful substances were marketed, made popular and adopted among ordinary family gardeners. ${ }^{14}$ One of my previous studies analysed the shifting cultural and social codes that shaped different generations of Norwegian pesticide and herbicide propaganda directed towards home gardeners in the decades from 1945 up to 1975. ${ }^{15}$ This current article will extend perspectives within Scandinavia by examining parallel sources from Denmark and Sweden for the years 1945-1952.

We need to keep in mind that insects, fungi, and plant viruses and weeds were not the only species that were systematically attacked by the joint efforts of the state and citizens in this period, carried out by using poison. All three Scandinavian countries had other animal eradication campaigns going on, where different types of poison were the preferred method. Norway and Sweden had carried out the state-run eradication of predators since the nineteenth century. All countries intensified their local rat eradication programs in the 1930s and 1940s, the so-called "rat wars." In addition they all had different poison campaigns against crows from the 1930s until around 1950; the "crow wars." 16 Forty Danish communities participated in the stateled campaigns against sparrows in the 1940s. Alas, social acceptance of killing animals with poisons and of the presence of strong poisons in their everyday surroundings, extended far beyond the use against insects or weeds. These practices were accepted, both at the state and the community level and presumably also by significant groups in the population who took part in the different types of poison practices that extended far beyond agriculture, forestry and professional gardeners. ${ }^{17}$ In the experts' recommendations regarding, and the commercial propaganda for, the use of different pesticide technologies in private gardens, no matter their size, the pesticide enthusiasts addressed general consumers, particularly the average gardening family. In Scandinavia, this is where the synthetic pesticides found their largest potential market outside commercial agriculture, before the producers and sellers of pesticides set their

\footnotetext{
${ }^{13}$ Bertomeu-Sánchez, "Introduction."

${ }^{14}$ One major exeption is Mart, Pesticides.

15 Ohman Nielsen, "Kverk krekene!"

16 May-Brith Ohman Nielsen and Anne Mette Seines, "Poison to the Beasts: Changing Poisons and Poisoning Practices in Campaigns to Kill Norwegian Birds and Mammals, 1845-1967," Environment and History 25, no. 3 (2019): 321-364. See also forthcoming works by Seines on rats as part of the research project "Deadly Dreams - The Cultural History of Poison, 1850-2020," accessed April 14, 2020, http://deadlydreams.no/. On the organised campaigns against sparrows in Denmark see Haven (hereafter cited as $H A$ ), 1942, 107.

17 Ohman Nielsen and Seines, "Poison to the Beasts."
} 
eyes on the potentially vast market in forestry, mainly from the mid-1950s onwards. ${ }^{18}$ Indoor pests also provided a potential market. However, not all households, homes, businesses or public buildings would need insecticide chemicals on a regular basis or in large quantities, nor as a routine or precautionary measure; neither would they require these chemicals for a series of seasonally changing insects with different characteristics, which might require different chemical remedies to eliminate. In contrast, any home gardener, with a large or a small garden, might experience insects or fungi of different types on their plants, throughout the year, and thus be persuaded to perceive them as a problem that required specific prescriptive technologies, even a series of preventive actions involving different types of chemical products throughout the year, and thus replace holistic gardening technologies with prescriptive ones.

With regards to plants, family gardens, whether grown for pleasure or self-supply, tended to be more diverse than the rational and efficient commercial gardens. Thus, the number of different types of potential insects and fungi that occasionally feed on the different species in these gardens through the seasons were more numerous. So, although diverse family gardens might not experience massive species attacks as did larger mono crop fruit or vegetable gardens, the market for pesticides among home gardeners was potentially huge. Not least in Scandinavia, where a relatively high percentage of families owned their own homes and a plot of land around their house and used this space for some form of gardening.

Between 1945 and 1952 most private gardeners in rural, suburban and urban areas, with the exception of densely populated inner cities, but including the urban colony and allotment garden societies, would grow a considerable amount of edible produce for home consumption; this would include vegetables, potatoes, fruits, berries, rhubarb and herbs, in addition to decorative plants. The variety of plants in these home gardens could, in theory, offer numerous possible host plants for a variety of pests, fungi and weeds throughout the year. Some of these caused general problems, like species of lice and mites. Others were very plant-specific such as carrot flies, cherry flies and cabbage caterpillars. The host plant's tolerance for different chemicals varied too. Removing the same insect species or weed from different plant species or different plant cultures often required different commercial pesticide products, or different solution combinations, in order not to kill the host plant. Thus, it was among these numerous family gardeners of Scandinavia, that producers and sellers of pesticides and herbicides found

${ }_{18}$ In Sweden pesticide spraying of forests from airplanes started already in the 1940s, but increased in the 1950 s, especially with the introduction of the new generation of synthetic weed killers. Harri Siiskonen, "Døden i de finske og svenske skoger. Pesticider i kommersielt skogbruk på 1900-tallet," in Ohman Nielsen, A selge liv og død, 47-59. In Norway pesticide spraying of forests started in the mid1950s and expanded rapidly in the 1960s. May-Brith Ohman Nielsen and Vidar Kalsås, "Spraying the woods. Pesticide adoption and pesticide controversies in Norwegian woods, 1953-1996" (forthcoming). Denmark had no wild forests and only a few cultivated ones, so the market for forest spraying chemicals was limited. 
their potentially widest audience among the general public. These many amateur gardeners, the majority of whom had family-sized gardens, were also consumers, citizens and voters. Thus, it is fair to assume that their knowledge, their attitudes and their habits regarding the use of pesticide technology had a significant impact on the forming of opinion in these matters. As they were conveyors of time- and space-specific "normality" and "common sense,"

- "the way we do things around here" - they probably had a far wider impact on politics and practices of pesticide technologies in society than the mere application of chemicals in their individual gardens.

To avoid excessive repetition of elements that were present in two or all of the Scandinavian countries, and to show them in more depth, I will concentrate on a close-up presentation of some of these elements in one of the countries. Because the pesticide promotion and instruction were far more intensive in the Norwegian Garden Association throughout the entire period 1945-1952, and the state-level actors were so central, I will first use the Norwegian case as the core case study of this element, and afterwards compare the material from Denmark and Sweden with the findings from Norway. I will focus on the Danish case when I show how the gardening associations organised the pesticide programs that their organisations prescribed, not only for their members and the readers of the magazine but for all Danish gardeners.

\section{The Norwegian Garden Association and the Magazine Hagetidend}

The roots of the Norwegian Plant Protection Agency, Statens Plantevern, date back to the early 1890s within the Department of Agriculture. From this point on a State Entomologist was the central expert in this office. In 1913 the position of State Weed Expert was established in this office, and in 1920 the agency set up the position of State Mycologist. Thus three scientific fields were represented in Statens Plantevern.

The World War II and the strain it put on food supplies led to new initiatives concerning the work against plant diseases, pests and weed problems. The State Institute for Plant Pathology was established in 1941, adding a specialised zoological section in 1943. In 1946 the institute changed its name to Statens Plantevern. A state decree from the occupant authorities in 1943 gave the governmental Director of Agriculture authority to decide whether a substance should be added to the Department of Agriculture's list of approved measures against plant disease, pests or weeds.

The Norwegian Garden Association, Det norske hageselskap, was founded in 1884 and had grown into an extensive national organisation by the 1930s. The membership magazine Norsk Hagetidend, (Norwegian Gardening Times), often just called Hagetidend, was published from 
the very first year onwards. ${ }^{19}$ The State Plant Protection Agency communicated to the public through Hagetidend as well as through agricultural journals and daily newspapers.

During World War II, a close system of communication and instruction was built between the agriculture authorities and the plant protection experts on the one side, and the farmers, gardeners and general public on the other. This system included a stream of information, decrees and messages from the agricultural authorities, spread through the general press, newspapers and daily radio programs, and in more specialised publications like magazines for farmers, gardeners and agriculture organisations. ${ }^{20}$

Hagetidend was the most widespread of all the general magazines in Norway in 1945. The number of subscribers, outside the gardening organisation itself, tripled in the war years from 3500 in 1939 to 9500 in 1946. Even steeper was the rise in copies sold of the Horticultural Society's most popular annual publication Minneliste for hagebrukere (The reminder calendar for gardeners), widely known as Minnelista. Minnelista was printed as a separate publication in the February issue of Hagetidend sent to all members and subscribers. The number of copies printed rose from 25,000 in 1939 to 52,000 in 1944 and reached one million in $1956 .{ }^{21}$ Norway had 3.5 million inhabitants at this time. This publication probably had subscribers in Denmark and Sweden as well. Minnelista was the authoritative gardening calendar. It told Norwegian gardeners what to do in their gardens and when. In some cases, e.g. pesticides, it also told them how to carry out certain tasks. From the late 1940s onwards, more than half of the contents was concerned with pests, diseases and pesticides and was written by the state entomologist and the state mycologist. A separate chapter on weeds, written by the state weed expert, presented the chemical means to eradicate unwanted plants. In this way Hagetidend and Minnelista proved the largest arena for exchange on gardening and plant protection between the national experts and authorities on the one hand and Norwegian gardeners on the other.

Like the other Scandinavian gardening magazines, Hagetidend had different content categories. In the editorial content and the editors' commissioned content as well as in Minnelista, the editors and the state experts presented their professional recommendations and gave instructions. The gardening magazines also printed commercial advertisements for products directed at gardeners. Between 1945 and 1952 pesticide ads were the most numerous and prominent of these, and they recommended products from the big international chemical companies and their Norwegian vendors. Here we can observe what the sellers of pesticides held to be the best promotional strategies, slogans, arguments, references and imagery. A third type of content consisted of questions and comments from the members and readers. This type

\footnotetext{
${ }^{19}$ Ohman Nielsen, Små paradiser, 16ff.

${ }^{20}$ Ibid., $143 \mathrm{ff}$.

${ }^{21}$ Norsk Hagetidend (hereafter cited as NH) (1946), 2; NH (1956), 26.
} 
of material was quite scarce in all of the Scandinavian gardening magazines between 1945 and 1952 , and only received more space and attention from the late 1950 s onwards. ${ }^{22}$

Until the onset of World War II a limited number of chemicals were used by Scandinavian gardeners, mainly among growers of fruit and berries. These were different products containing nicotine, lead arsenate, lime sulphur, blue vitriol, copper and tar oil. Cyanide gas was also used in greenhouses by professional gardeners. These were all acutely toxic to humans. Often the dose was hard to get right when the gardeners mixed the products for different plants at different times of the season. So there was almost always a risk of killing both the pests and the plants, especially for less experienced home gardeners.

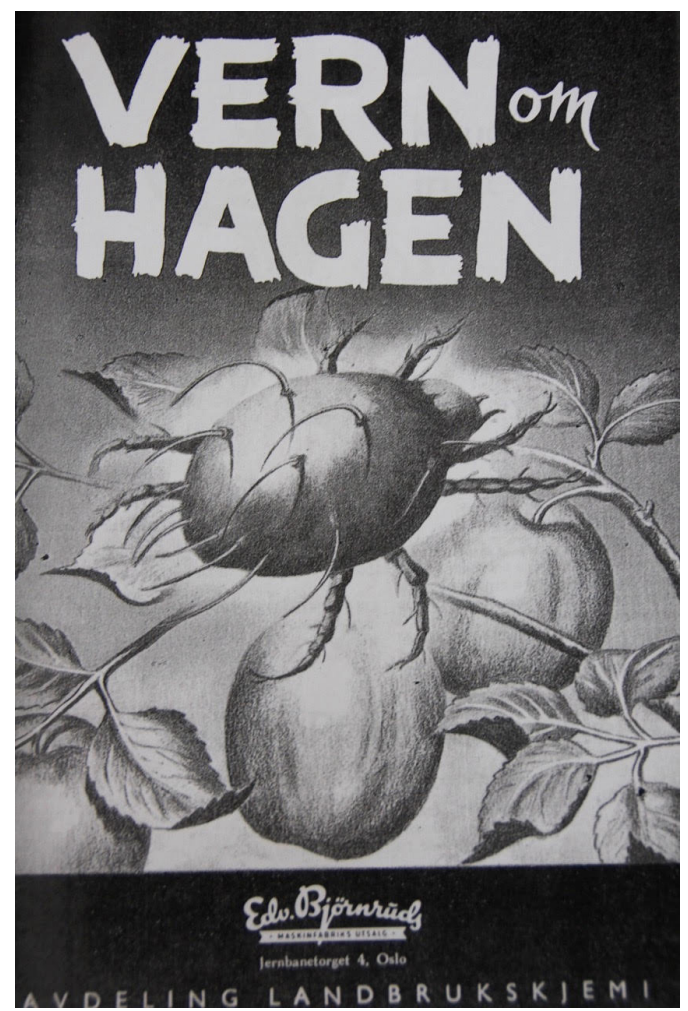

Figure 1 - Norwegian giant mite ad.

Many of the pesticide ads featured giant insects attacking garden plants. This commercial in Norsk Hagetidend shows a mega size mite approaching an apple tree.

Norsk Hagetidend (1948), photo by May-Brith Ohman Nielsen.

Between 1945 and 1970 Hagetidend and Minnelista were major storytellers of chemical modernity and chemical worldviews. This position was quickly established after 1945 and

${ }^{22}$ Ohman Nielsen, “Kverk krekene!”; Ohman Nielsen, Små paradiser. 
consolidated in the years 1945-1952. Hagetidend printed all the reports and communications related to plants that were published by the State Plant Protection Agency and the Department of Agricultural Chemistry at the State Agricultural College. Together these two institutions were responsible for the process of approving new pesticides for the Norwegian market. Here we will focus on discussing the introduction and presentation of and recommendations concerning three major new products in the 1940s: DDT, Parathion or E 605 and Lindane, often named Hexa 6.6.6.

Only a very few critical voices were admitted to the columns of Hagetidend and only for brief entries and usually with contradicting arguments and assurances from the pesticide authorities. Among the critical voices were a few biology teachers, several beekeepers and one female entomologist. ${ }^{23}$ The use of DDT and other poisonous and harmful pesticides was challenged by Astrid Løken, a Norwegian entomologist, in Norsk Hagetidend several times in the years between 1945 and 1962. But her articles and views were fiercely rejected and even ridiculed by the magazine's experts. ${ }^{24}$

The insect-killing properties of DDT were discovered in Switzerland by Paul Muller in 1939. From 1942 on the Allied powers used DDT in camps and battlefields to kill insects that brought different types of disease, like malaria and typhus, and to disinfect the bodies, clothes, equipment and quarters of soldiers, prisoners and wartime refugees. DDT was widely popular at the end of the war and was often praised along with the atomic bomb as the decisive new measure that helped the Allies win the war. By 1945 DDT had obtained a strong aura of patriotism and safety. DDT had "saved Allied lives," and many Allied soldiers, but also civilians, had been powdered with DDT to get rid of lice and other bugs, receiving the impression that DDT was useful, harmless and a blessing to the free world. By the time the war ended, the producers of DDT had developed an enormous production capacity. However, the military now only needed a fraction of this production, and thus the producers and sellers of DDT set their eyes on other possible markets and consumer groups. DDT had already been introduced in agriculture and forestry in some countries. In addition, it was widely used for sanitary purposes. ${ }^{25}$ But huge new markets, outside these sectors, opened up in the Scandinavian countries among the many family gardeners. ${ }^{26}$

${ }^{23}$ Ohman Nielsen, "Kverk krekene!"; Ohman Nielsen, Små paradiser. For beekeepers, see also Anne Jorunn Frøyen, "Influencing for Results: Bees, Beekeepers and Norwegian Pesticide Legislation,” HoST - Journal of History of Science and Technology 13, no. 1 (2019): 28-50.

${ }^{24}$ Astrid Løken, "Er DDT, Heksa og E 605 ufarlige for folk og fe," NH (1948), 190f. She recommended a wait-and-see attitude towards these new chemicals and not to start using them until their effect on "the human organism" was properly examined and mapped.

${ }^{25}$ Kinkela, DDT and the American Century; Mart, Pesticides; Bertomeu-Sánchez, "Introduction."

${ }^{26}$ Ohman Nielsen, "Kverk Krekene!”; Ohman Nielsen, Små paradiser. 
Parathion, also called E 605, was the active ingredient in Bladan. Parathion was patented and produced by the German companies I.G. Farben and Bayer from the early 1940s onwards. After the end of World War II it was also produced by Allied countries which had seized the patents at the end of the war. Parathion is highly toxic to most insects, fish, birds and other wild and domestic animals. It is also acutely toxic to humans, through contact, swallowing and inhalation, even in minute doses. Most of the pesticide-related accidents that occurred in Scandinavia after World War II, as well as suicides and poison killings, involved Parathion products. A major reason was that Bladan was used for so many purposes and in so many areas of people's everyday lives and was thus widely available. The substance was marketed as the universal remedy for all types of unpleasant creatures that people wanted to get rid of, both inside and outside their homes.

Lindan, also known as gamma-hexachlorcyclohexane, was the main active ingredient in Hexa 6.6.6., which was the marketing name. The substance was produced by the British Imperial Chemical Industries Ltd. from 1942 onwards. Lindan products like Hexa 6.6.6. were widely used in agriculture from the mid-1940s onwards, but also as a pharmaceutical measure against lice and scabies among humans and domestic animals.

In Norway, the gardening association and Hagetidend were both the main and the widestreaching arena for the promotion of these chemicals from 1945 and 1946 onwards. The gardening magazine cooperated closely with Norwegian pesticide experts and the state plant protection authorities, and recommended DDT, Bladan and Hexa 6.6.6. warmly. Hagetidend was a strong advocate for "systematic planning" and "precautionary spraying" against all possible pests and diseases. As early as 1946, several years before the Danish and Swedish gardeners, members and readers of the Norwegian magazine were pushed to adopt prescriptive pesticide technologies. They were told that all Norwegian gardeners needed a systematic spray plan for their fruit trees, berry bushes and vegetables, and all family gardeners and members of local gardening clubs were urged to organise joint spraying in their area to make the spraying efforts "rational and effective" and, if needed, to engage professionals to carry out the spraying. ${ }^{27}$

Norway's leading experts in the scientific field of pesticides were at this time the same individuals who, in their positions as state authorities, were in charge of national plant protection administration. They also put together the recommendations and the guidelines in Hagetidend. In the mid-1940s, this group of experts consisted of far fewer people in Norway than in Denmark and Sweden, where the agrarian sector was much bigger. This may partly explain why there seemed to be less discussion, fewer critical voices and fewer reservations

${ }^{27} \mathrm{NH}$ (1946), 90. See more about these spray circles in the presentation of the Danish gardening association and their magazine. 
among the Norwegian plant protection experts in Hagetidend than in the Danish and Swedish gardening magazines, where experts were numerous. ${ }^{28}$

These close and intricate links between commercial interests and the public offices that were set to govern the field were created seemingly without any objections in Hagetidend. At times some pesticide producers and sellers appeared to have had fairly open columns, yet they faced few critical questions. They promoted their new chemicals and attacked people who warned that the chemicals might be harmful to humans and useful animals, and they induced the plant protection authorities to support them. The rhetorical strategy adopted by Henry Frogn, manager of the company Hans Clausen A/S, who imported the first DDT products in 19451946, was typical for this period. And so was the way the Norwegian plant protection experts and state pesticide administration came to his support. According to these experts, the world of science, all reason and good values sided with the pesticide, as readers and members were told in the first issue of 1946:

Hundreds of agricultural test facilities and equally many medical research institutes all over the civilised world have in recent years dealt with results from tests performed with the epoch-changing DDT agents. Extraordinary results have been achieved in the fight against a wide range of different pests. Public reports praise the great advantage of DDT products over the alternative products based on arsenic or nicotine, because DDT products are harmless to humans and warmblooded animals. ${ }^{29}$

equally typical was the support that the state entomologist Schøyen gave Frogn:

The designation DDT is exclusive and applies only to the non-harmful Geigy products used for disinfection and insect eradication. [...] I underline that these products are absolutely not harmful - and therefore I have included them in Minneliste for Hagedyrkere $1946 .^{30}$

The quote is one of many examples of how the leading national scientific experts behind Minnelista presented their recommendations in close accordance with the interests of the pesticide producers and backed their information without reservations. It also illustrates how Minnelista was constructed, as the most authoritative voice of the leading national experts in the field. This gave rise to a dual logic; the truth was any fact that was written in Minnelista, and, because some facts could be read in Minnelista, they were true.

Øystein Husaas, who worked for both the State Plant Protection Agency, as leader of the test program, and as a consultant for some of the pesticide companies, supported both his superiors in a later article titled "More about DDT." According to Husaas, DDT was a

${ }^{28}$ Ohman Nielsen, "Kverk krekene!"

${ }^{29} \mathrm{NH}$ (1946), $14 \mathrm{f}$.

${ }^{30} \mathrm{Ibid}$. The italics are from the original source. 
splendid replacement for the old arsenic products and quite harmless. His article followed a rhetorical strategy adopted by many of the DDT-supporters; they presented their foremost critics as unserious and ignorant: "Everything suggests that (the opponent) does not have any knowledge of the test that has been performed with DDT-products." ${ }^{11}$ The full-page advertisements from Hans Claussen A/S promoted "Original Geigy DDT. The new weapon in the battle against pests and parasites on plants, animals and humans" now filled most issues of Hagetidend. ${ }^{32}$ These ads told readers that DDT from Geigy was epoch changing and unique due to its exceptional effectiveness, while being harmless to humans and domestic animals. Among these Geigy DDT products were Gesarol against flies in farm buildings, and Neocid against bedbugs, lice, fleas, cockroaches, ants and other unwanted creatures. The new Hexa 6.6.6. products were introduced by the editors of Hagetidend in exactly the same way in their editorial column a few issues later, titled "The revolutionary insecticides, 6.6.6. or HEXAproducts."

Like the weapons of the battlefields that went through a major transformation during the last war, and reached their highest level in the atomic bomb, the weapons against insects have gone through a huge development and reached their final peak, so far, with the new D.D.T. and 6.6.6. products.

Even if these pesticides, like the atomic bomb, do not put a final end to all ongoing warfare, one has still achieved the production of products with hitherto unseen effects, while still being harmless to man and domestic animals. ${ }^{33}$

The pesticide expert's article in this issue explained to Norwegian family gardeners that the 6.6.6. products were even newer than DDT, and that 6.6.6. and HEKSA were

a convenient abbreviation of hexaklorcyclohexan, the name of the agent. (...) This in fact contains 6 carbon, 6 hydrogen and 6 chloride atoms in the molecule $(\mathrm{C} 6 \mathrm{H} 6 \mathrm{Cl} 6)$ and from this comes the name HEKSA which means six (in addition to having a phantasy name!). ${ }^{34}$

Hagetidend told its readers that insecticides could work in three ways: 1) Inhalation poisons, 2) Intestinal poisons, 3) Contact poisons. While the old pesticides only had one of these poisonous effects, and thus were "one sided," international research on the new 6.6.6. products showed that these had "dual or triple effects" because they had powerful effects as both contact and intestinal poisons. And, in contrast to DDT, due to evaporative effects, 6.6.6. even had some inhalation poison effect as well. The strong poisonous effect of 6.6.6. was caused by the

\footnotetext{
${ }^{31}$ Øystein Husaas, “Mer om DDT,” NH (1946), $50 .$.

${ }^{32}$ See for instance $N H$ (1946), 120.

${ }^{33}$ Ibid., $132 \mathrm{f}$.

34 Ibid. HEKSA (Norwegian heks) refers to a witch, someone who makes evil magic and brews poisonous elixirs. The sources use both the terms HEKSA and HEXA, sometimes capital letters and sometimes not.
} 
chemical penetrating the insect's "panzer" and "paralysing the nervous system." 35 The effects in living insects were really spelled out for readers to enjoy. Importantly, the editor claimed that 6.6.6. was harmless to humans and domestic animals. ${ }^{36}$

Norwegian gardeners were told that Heksa had proven to be "150 times more effective in the fight against the locust" than previous products and was extremely effective against mosquito larvae. Minute amounts of the poison, just one kilo of HEKSA with 5 percent 6.6.6. per acre, had proven sufficient to more or less exterminate the mosquito larvae. It was also proven to kill houseflies efficiently. In England, 6.6.6. was most famous for its effect on soil beetles. Hexa killed more soil beetles than DDT immediately, but precautionary dusting was necessary, the expert argued. Hagetidend explained that it was self-evident that the powder should be applied early, immediately after the plants had germinated or the seedlings were planted in the ground. 6.6.6. was cheap to use, even on larger fields, and thus it was economically wise to dust the plants once they had germinated and to repeat the dusting after strong rains. The Heksa pesticides had also proven their effect on other insects that gardeners might find annoying, such as ants, apple flea beetles, apple blossom weevils, raspberry beetles, cabbage caterpillars, and woodlice, and represented a new dawn in the fight against soil-living pests such as click beetle larvae and crane fly larvae. The editor's post-script applauded this recommendation and stated that testing by experts was the definite answer to the question of which remedies to use in gardens. ${ }^{37}$

Today we would think that these "superior effects" demonstrated the environmental problems of this generation of new pesticides. But at the time, the toxicity and the lethality of the products were promoted as superior attributes. The objective was to kill as many insects as possible in gardens, fields and in the surroundings. Texts like these illustrate the need to study contemporary knowledge and mind-sets as elements of pesticide technologies.

Between 1945 and 1952 the Norwegian gardening associations, Hagetidend and Minnelista recommended specific pesticide products available on the market. From 1953 onwards, in accordance with new regulations on classification and labelling, Hagetidend and Minnelista and their expert articles on pesticides recommended the active substances in many types of pesticides, in order not to favour one producer or seller of DDT, Lindan or Hexa over another. The intricate connections between producers, experts and editors of Hagetidend were, nevertheless, kept up for decades. ${ }^{38}$

The close connections between editorial recommendations and commercial promotions

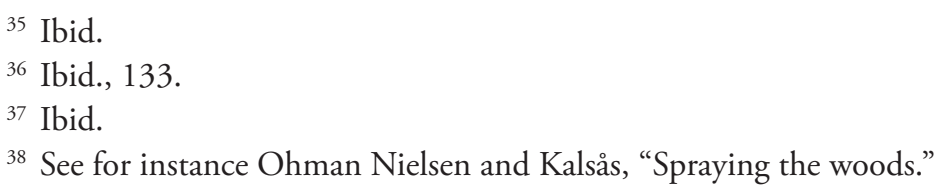


can also be observed in the introduction of the new popular product Bladan or E 605, a thiophosphorous chemical produced by Bayer and marketed in Norway by Edin \& CO. The first big ads for Bladan were printed in the spring issues of 1949 and referred directly to Minnelista. "Rationalise your spray plan!" the ads told Norwegian gardeners, illustrating their message with a glossy, spotless apple. Bladan was active against most pesticide problems and could replace numerous other products and be used in all three routine sprays through the season, the promotion claimed. If used according to the instructions, it was claimed, the product was harmless. Bladan E 605 was less toxic than nicotine and could not be accumulated in the body, the massive commercials told members and readers. ${ }^{39}$

The messages and symbols in the "battle" against the "beasts" were supported by the rhetoric of the ads for the new hormone-based anti-weed chemicals launched in the summer of 1947. A decisive battle was coming: "All weeds and all hordes of unwelcome guests in the garden are dormant now, but right now, before they wake up to a new attack, is the time to inspect the arsenal and ask yourself if there is order in your defence of the garden," said Hagetidend. ${ }^{40}$ The illustration featured a man with a backpack spray-can spraying cabbages, captioned "Deathrays against the earthworms." 41

In the publications of the Norwegian gardening association the subject of garden chemicals promoted strong ideas of specialisation and professionalization closely integrated into a prescriptive technology. The experts basically told family gardeners that they were ignorant and not qualified to make decisions about their own garden with respect to insects and disease, but had to follow expert advice. This was the irony of the poison in home gardening, as in many other arenas. It was the supposed scientific experts who pushed the excessive use of poison, in close understanding with major producers of pesticides, vigorously claiming that these substances were harmless to humans and domestic animals. These same groups also continued to expand the space for the application of these chemicals. In the universe that was imagined in these commercials and in the expert and editorial comments the arena for garden chemicals was almost boundless. Insecticide and herbicide commercials in Havetidend told gardeners to spray and kill "all pest insects," "everywhere insects breed," to spray weeds in borders, fields, lawns, driveways, roadsides, ditches and "everywhere weeds are found." 42

These spatial demarcations were purposely vague and flexible. Gardeners, and all other

\footnotetext{
39 See $N H$ (1949), ad section around p. 89 and numerous following ads, among them NH (1949) around pp. 122 and 132. See also the two-page ad for Fosforkverk from the same producer based on Thiofosfor E 605; NH (1949), ad section around p. 141; NH(1953), p. 41 and around p. 64.

${ }^{40} \mathrm{NH}$ (1948), 53ff.

${ }^{41}$ Ibid.

${ }^{42} N H$ (1948), ad section around 92, see also ads for "2,4-D Weedone for lawns, pasture and other grass fields" and "Dow Selective in grain and peas" from Edv. Björklund, Ibid.
} 
consumers, were told that there were no limits if they wanted to get rid of something they disliked. This was not limited to rational calculations of cost and benefits in their gardens but extended far beyond. The worldview and aesthetic ideals of the poison sprayer himself were the norm. These commercials pushed the dream of a world where all unwanted creatures were eradicated, because people just did not like them, and now they finally had the effective means to exercise their antipathies. ${ }^{43}$ This "all over" rhetoric was introduced in 1946 in the famous American promotional film "Pestoy DDT - Let's put it everywhere!” and soon spread to pesticide campaigns in many countries and really took off with the promotion of new hormone-based weed chemicals. ${ }^{44}$

Norwegian gardeners were not advised to spray because they had pest problems. They were told to spray according to a set plan because they were going to have pest problems. Both experts and ads listed an endless catalogue of insects that were prepared to attack at any time. This was part of the self-confirming elements of this prescriptive technology. Gardeners should not believe that they were able to understand a bigger picture, even in a small garden, or trust their understanding of a more holistic technological approach to gardening. Now the rowan moths are coming! Now the gooseberry mites! And now the cherry flies! These were the repeated war cries in the columns of the gardening magazine between advertisements figuring giant pictures of all the possible insects that might show up in a garden. Just like Danish gardeners, the readers of Hagetidend were told they were a disgrace to their neighbours if their gardens were safe havens for pests. ${ }^{45}$

Between 1945 and 1952 the ads for pesticides were mainly presented through two explicit clusters of imagery. The most influential were war metaphors and references to both World War II and the emerging Cold War. ${ }^{46}$ The other was the world of folktales and folklore, where individual insects were given a personality and bad intentions. Insects were depicted as the enemy on the open battlefield or lurking right behind you, sometimes tagged with Nazi or communist symbols. The war on bugs was an epic battle between good and evil forces. Words like "kill," "death," "fight down," "eradicate" and even "Doomsday" were evident in the Norwegian ads, and also to some extent in the Danish and Swedish magazines. ${ }^{47}$ These rethorics were known figures from American pesticide campaigns and later got an even wider popular audience in

${ }^{43}$ Ohman Nielsen, "Kverk krekene!"

${ }^{44}$ Ibid.

${ }^{45}$ Ibid. Regarding Danish gardens see below.

${ }^{46}$ This is a similar finding to what Edmund Russell have previously found in his studies of pesticide propaganda in the US and beyond, Edmun P. Russell, "Speaking of Annihilation: Mobilizing for War Against Human and Insect Enemies, 1914-1945," The Journal of American History 82, no. 4 (1996): 1505-1529.

${ }^{47}$ Regarding the Danish and Swedish magazines, see below. 
the Big Bug Movies. ${ }^{48}$ In the Norwegian magazine, the spraying gardener was often depicted as a military hero, a resistance fighter, or a knight in armour who fought the hordes of insects single-handedly with the help of the new pesticide technologies. ${ }^{49}$ The man with the backpack spray equipment soon personified the professional gardener in Hagetidend, and several schools that trained gardeners featured this image in their promotional material. ${ }^{50}$

The tools for spraying were also presented as weapons of total war, displaying unprecedented power. Among them were the big sulphur steamer Vesuvius, that spread sulphur and nicotine steam, as did Atomisator and Zyclon. The Danish Orkansproyten (the hurricane spray) resembled a battle tank, carrying 1500 litres of chemical solutions and spraying 200 litres a minute. ${ }^{51}$

The patriotic appeal to poison pests was an established rhetorical figure in the rat and crow eradication campaigns in the 1930s and 1940s, and from there it was adopted by the pesticide promoters. ${ }^{52}$ Norwegian family gardeners were told that insects robbed the country of millions every year and that they should fight soil beetles and other bugs for their country's sake.

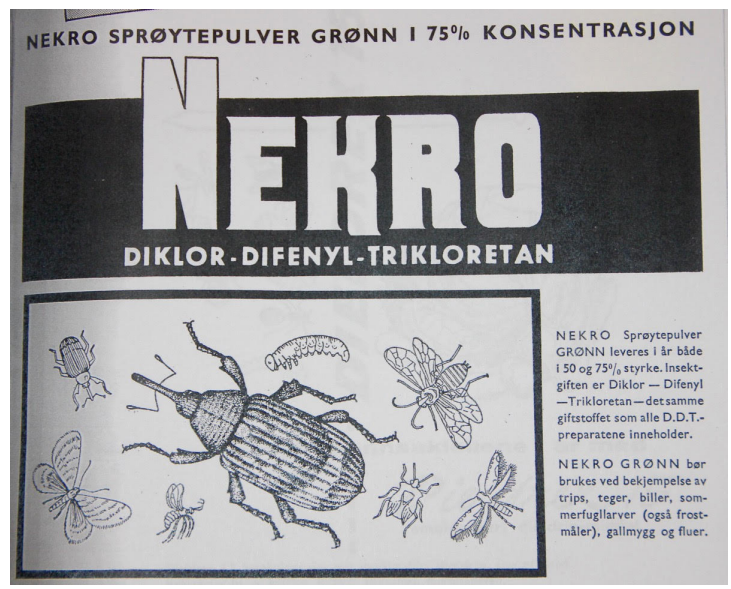

Figure 2 - Nekro Norwegian ad.

Many of the pesticides were marketed with morbid or devilish names and slogans like death or kill in combinations with chemical formulas connoting science. The DDT product Nekro was marketed in Norsk Hagetidend as a means to kill most kinds of insects. Norsk Hagetidend (1949), photo by May-Brith Ohman Nielsen.

\footnotetext{
${ }^{48}$ William M. Tsutsui, “Looking Straight at 'Them!' Understanding the Big Bug Movies of the 1950s, Environmental History 12, no. 2 (2007): 237-253.

${ }^{49}$ Ohman Nielsen, "Kverk krekene!"

${ }^{50} \mathrm{NH}$ (1949), front cover of the February issue, the issue with Minnelista included. The same image figures twice on the front cover, and also sometimes inside the magazine. See also ads for Dytrol from Shell, $N H$ (1953) around p. 44; $N H$ (1954), around pp. 23, 51, 64, 157.

${ }^{51}$ Ohman Nielsen, "Kverk krekene!"

52 Ohman Nieslen and Seines, "Poison to the Beasts."
} 
In the years between 1945 and 1952 it was apparently a commercial advantage if the pesticides had names that displayed their extraordinary toxic effects as well as giving out a scientific and technological allure. Among the names on popular products were Toxin, labelled A, B, C, D, X and Q, directed "against all pests." Nekro was marketed in three types, green, blue and yellow. Agrocide with 6.6.6. was sold in types 1, 2 and $3 .{ }^{53}$ Black Leaf was a popular nicotine spray liquid that covered leaves with black spray, and the chemical name 6.6.6. obviously referred to The Beast in the biblical Book of Revelations. ${ }^{54}$

Minnelista of 1952 shows us the recommendations and instructions given by state pesticide experts to Norwegian family gardeners. From a modest start as a garden calendar, this publication, with more than a million copies printed annually, ${ }^{55}$ had turned into the decisive Norwegian prescriptive poison manual for all types of gardening. Most of the new post-war pesticides were now on the market and had been tested by plant science experts in state test programs. Between the full-page ads from the pesticide producers, gardeners could read experts' advice on pests and diseases concerning fruit, berries, vegetables, potatoes and other plants. ${ }^{56}$

The presentation of disease and pest problems of potatoes and vegetables listed ten general problems that could affect different types of plants and soils. Nine of these were organic, listed as: earwigs, seed bugs, May bugs (cockchafer), click beetles, crane flies, moths (cutworms), snails, white mould, and grey mould. It was claimed that DDT, Heksa and other strong poisons like cyanamide and thiophosphorous should be used against these eight problems. Against the other 29 diseases or pests that could attack specific plant families or species, except for potato rot, the state experts recommended precautionary spraying or powdering with DDT or Heksa. This included four out of five problems concerning peas and seven out of ten problems for cabbages. For fruit trees and berry bushes the instructions read as follows:

The standard sprayings (1, 2, 3 and 4) that we recommend for each type of fruit should be carried out by everyone. How many of the other sprayings (a, b, etc.) that should be done, must be adapted to conditions in the actual locality. ${ }^{57}$

For fruit trees Minnelista prescribed four annual standard sprayings with DDT or a thiophosphorous product (usually Bladan) against insects, with the extra addition of sulphur and copper products in the spray mixture against scab. On top of this, the Norwegian experts prescribed at least six additional obligatory sprayings through the seasons against mites in

\footnotetext{
${ }^{53} \mathrm{NH}$ (1947), ads section around p. 134 and later issues.

${ }^{4}$ Ohman Nielsen, "Kverk krekene!”

55 The publication was not only used by gardeners but also by farmers and others.

56 Minneliste for hagedyrkere (1952), see especially pp. 17ff and 29ff. The leader of the State Plant Protection Agency at the time was Sømme and the research leader was Husaas.

57 Ibid. Local conditions in general meant the local climate depending on altitude, latitude and wind exposure.
} 
winter, brown rot (monilia) in spring, against rowan moths, mites and lice in summer, and mildew and additional "extra scab sprayings" before harvest. Half of these sprayings should be carried out with DDT or thiophosphorous, the rest with sulphur, nicotine or mineral oil. These sprayings should be a precautionary routine and should not await an attack of pests or fungi. ${ }^{58}$ For other fruit and berries these same chemicals should be applied as follows: pears five sprayings; cherries and plums four sprayings; black currants and red currants three sprayings; gooseberries and raspberries two; strawberries four. The only warning that Norwegian gardeners were given in this connection was the following: because arsenic, DDT, hexachloride and thiophosphorous products are poisonous for bees and bumblebees, it was illegal to spray or powder these on open flowers. Flowering weeds under trees must be cut and flowering berry bushes covered before spraying starts. Use spray fluids lavishly, so that trees are thoroughly soaked, said Minnelista. ${ }^{59}$ In this way, and through the association of amateur and professional gardeners, the pesticide experts and prescriptive pesticide technologies usurped the idea of what it meant to be a good gardener.

\section{The Swedish Gardening Association and their Magazines}

In Sweden the national pesticide policy was administrated through Statens Växtskyddanstalt, the State Plant Protection Agency. Earlier, this authority was part of the state test program for agriculture and agricultural entomology, but it was singled out as a separate institution in 1932. Due to the rapid expansion of the field of plant protection in the late 1930s and 1940s three local sub-departments were established in Alnarp (1939), Linköping and Skara (both 1948). Southern Sweden was mainly an agrarian landscape with low, fertile plains, while the northern parts were mainly woodlands with an extensive forestry and timber industry.

In Sweden there were numerous local garden associations before the World War II. One of the oldest was Sveriges Pomologiska Förening (Sweden's Pomological Society), founded in 1900, with a special interest in growing apples and other fruit. ${ }^{60}$ In the early years this organisation sporadically published material on different topics concerning growing, harvesting and conserving fruit, and from the 1920s on also some articles on how to build up commercial production of fruit. From the1930s they published the regular periodical Fruktodlaren (The fruit grower). This was a membership magazine for the members of the association, and specially dedicated to fruit growing. Fruktodlaren addressed both amateur home gardeners and the rising number of rural fruit gardeners who aspired to make an income from fruit

\footnotetext{
58 Minnelista (1952), 29ff.

59 Ibid., 32f. About the legislation with regards to bees, see Frøyen, "Influencing for Results."

60 The association changed its name in 1965 to the broader name Riksförbundet Svensk Trädgård (The National Association of Swedish Gardens), more in line with the tradition established with Hemträdgården, and after the garden associations in Northern and Southern Sweden had merged.
} 
production by selling their fruit on the market and expanding their fruit garden and making it more rational, effective and adapted to the types of fruit that the market demanded. ${ }^{61}$ From 1943 onwards Fruktodlaren and Sveriges Pomologiska Förening pioneered the introduction and promotion of synthetic pesticides among Swedish amateur and professional fruit gardeners. ${ }^{62}$

In the early 1940s, there were two other Swedish gardening magazines published on a regular basis. Täppan ${ }^{63}$ was published by garden associations in Southern Sweden three to four times a year, and focused on decorative plants, flowers, bushes and trees, on park landscapes, decorative gardening and landscape design, but also on wildflowers. Because of its mainly aesthetic orientation, Täppan had less focus on the production of edible garden products, but the commercial and expert promotion of pesticide technologies was still clearly visible in this magazine. ${ }^{64}$

The third Swedish garden periodical in the early 1940s was the new Hemträdgården (The home garden). This magazine was first published as a yearly membership magazine for the garden associations of Northern Sweden, covering the part of the country from Stockholm and north. Hemträdgarden was aimed at family home gardeners and it soon became the most widely spread and read. This magazine is therefore the most obvious parallel to the Danish and Norwegian magazines discussed above, but Fruktodlaren also covers part of the same group. Hemträdgarden centred around the smaller family garden with a combination of self-supply cultivation of fruit, berries and vegetables as well as some decorative plants to make the garden inviting. In the early spring of 1945 the pomological society stepped up its ambition for a new magazine after its new book, Hemträdgårdens Frukter och Bär, edited by Yngve Lundin, a basic guide book on fruit and berries for home gardeners, proved a huge success in $1944 .{ }^{65}$ With Lundin as editor the society wanted to turn the magazine into a broad general gardening magazine for gardeners all over Sweden, expanding to first four and then six volumes a year and thereby reaching readers beyond the members of the garden associations and the 6000 regular subscribers. Editorial campaigns were launched to sell Hemträdgården in bookstores, magazine kiosks and institutions. ${ }^{66}$ Because of this editorial divide between the gardening magazines of

${ }^{61}$ Fruktodlaren (1930-1940).

62 See below.

63 Täppan directly translated means "the carpet," poetically referring to the green carpet of plants and flowers that covers the earth, and that is especially pleasing in parks, gardens and areas with beautiful wildflowers.

${ }^{64}$ In the early 1960s, Täppan merged with the far more successful Hemträdgården after the national organisation of Swedish gardening associations was consolidated.

${ }^{65}$ Yngve Lundin, Hemträdgårtdens Frukter och Bär (Stockholm: Sveriges pomologiska förening, 1944).

${ }^{66}$ Hemträdgairden (hereafter cited as $H E$ ) (1945), 24, 53. The magazine announced a competition about its name and on recruiting subscribers. Publishing two volumes in 1945 was a "test" of the market. It was obviously a success because in 1946 Hemträgärden was published in four volumes in one year, and in the next years the magazine was stable with six volumes annually. 
Sweden, between the dedicated fruit growers who were the target audience of Fruktodlaren and the average home gardeners who were the readers of Hemträdgairden, the communication on pesticide technology issues was quite different in the two magazines.

Fruktodlaren presented the new State Plant Protection Agency to its readers in the war years and advised on how to manage pesticide spraying despite the troubles and shortages of chemicals and manpower due to the war. ${ }^{67}$ Fruktodlaren was a strong advocate of chemical pest control, of adopting new synthetic pesticides, of precautionary spraying and applying a variety of different chemicals in repeated sprayings throughout both the growing season and the winter. The original Geigy DDT, Gesarol, had been introduced in neutral Sweden by 1943 as an insecticide in gardening and agriculture, and by early 1945 three Swedish producers were licenced to produce DDT-based pesticides, so there were four more or less similar DDT products on the Swedish market, Gesarol, Alltox, Boxol and Rotoxol. O. Ahlberg at the State Plant Protection Agency presented these DDT products with great enthusiasm to the readers of Fruktodlaren early in 1945 under the title "Epoch-changing remedy against pests." The testing of these products performed by the State Plant Protection Agency had shown good results against a long list of insects, including flies, according to Ahlberg. A farm could from now on be kept almost fly-free, providing a great improvement to hygiene, especially in dairy farming:

Despite its toxicity to many insects, DDT is in practice harmless to humans and domestic animals, and can therefore be used in many situations, where other insecticides have to be avoided. In practice it has been shown to be quite harmless to bees and bumblebees, and this is why one, without discernible risk, can use the substance on plants that are visited by these insects. Although we still have much left to research regarding DDT, we can now already safely claim that it to a high degree helps the effort to eradicate a number of pests, and that it in some cases makes it possible to eradicate types of pest that were formerly hard to get at. In this way the DDT-products have made it possible for us, without harm to humans and domestic animals, to fight pests in agriculture and in forestry by dusting from the air. Aircraft dusting of forests started already last year and this year especially the cultivation of oil-producing plants [transl: oljeväxter] in Southern Sweden will benefit from this new pesticide technology we now have in our country. ${ }^{68}$

The 1945 issues also included large advertisements for both traditional pesticides and the new DDT-based chemicals, "tested all over the world," among them Boxol, Alltox and Gesarol, which promised to "KILL the pests" while being harmless to humans and domestic animals,

${ }^{67}$ Fruktodlaren (hereafter cited as FR) (1941), 23, 39ff; FR (1944), 125. See also the ads through 19411945. On the main objective of making Swedish fruit production for home consumption and sales more effective and profitable, see also O. Stoy, "Nogot om sprutvätskor," FR (1945), $21 \mathrm{f}$.

${ }^{68}$ FR (1945), 97ff. 
and in practice also to bees. ${ }^{69}$ From this time on Fruktodlaren was packed with advertisements from the big pesticide companies. Among the most aggressive appeals to kill insects in 1945 and 1946 were the commercials run by Shell and Olsens Enke, but other producers and sellers of pesticides soon followed this line. Most adopted the same figures of thought that we found in the Norwegian gardening magazine: the rhetorical appeal of "kill," "death," "deadly," "war" and "fight," the medieval knight in armour spraying the attacking hordes of insects and close ups of giant insects attacking and eating plants. Violently killed insects were also a favourite illustration in this Swedish magazine, but the most typical death scene here was not rooted in folklore but evoked the imagery of the grand opera or crime movie. Under the heading "Drama in your garden," a fat bug was pictured on stage singing "Help me, I die!," with operatic gestures, surrounded by a chorus of insects, and an implied appeal to the readers to applaud the grand finale and execute the triggering events of the scenario. ${ }^{70}$ The aim was to mould mindsets that accepted and embraced pesticide technologies.

${ }^{69} F R$ (1945), 1, the ad for Geigy DDT from A/B Norrköping. See also the following issues in 1945 and 1946.

70 See for example $F R$ (1946), 1, inner cover, 183, inner cover, $F R$ (1947), 1, inner cover and the subsequent issues over the next two years. See also FR (1949), vol. 3. 


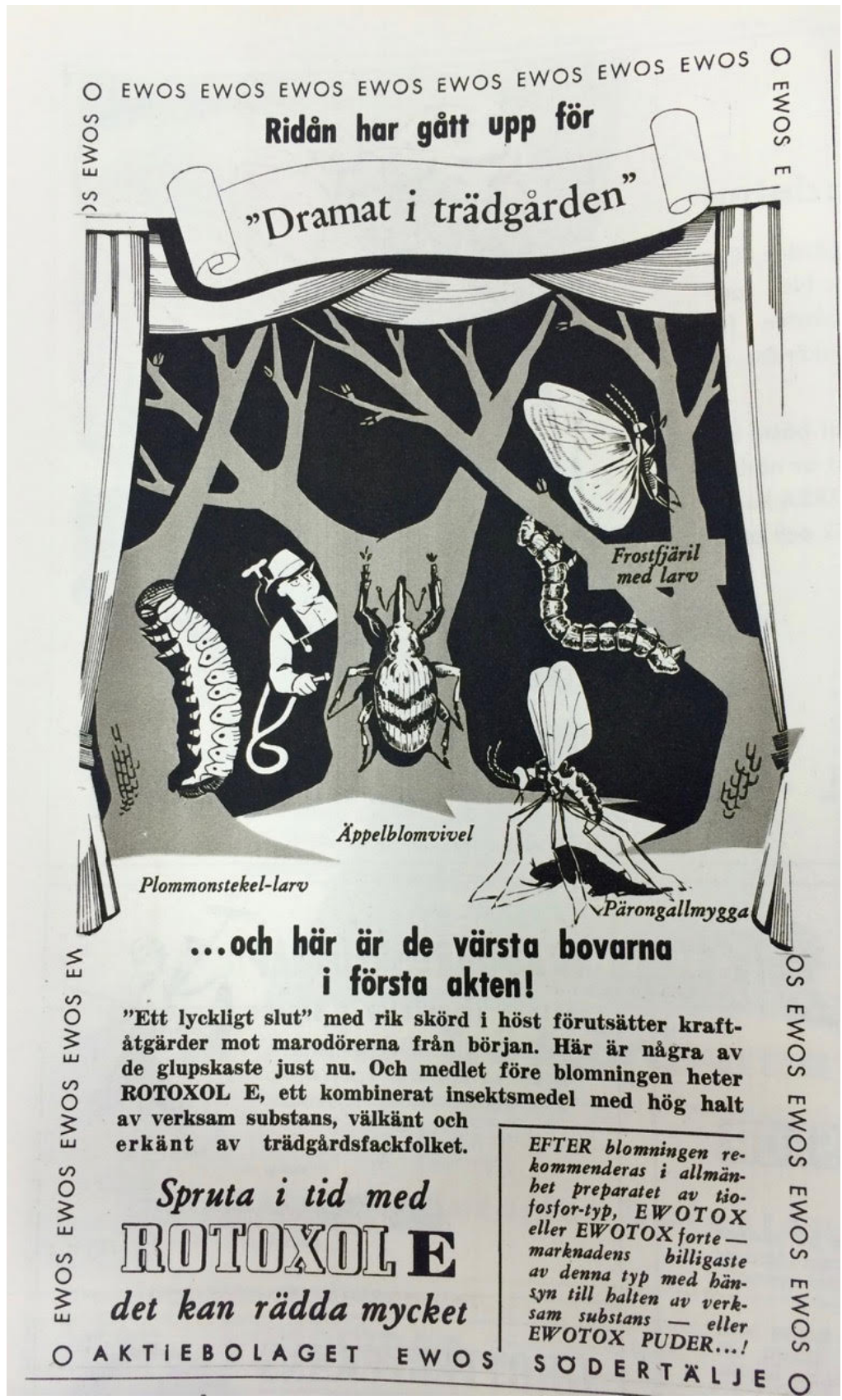

Figure 3 - Swedish drama in the garden ad.

The Swedish garden magazines printed ads presenting gardens as a stages for a big drama. The villains of the first act were numerous species of hungry insects challenging the heroic gardener and his trusted companion, the spray can with Rotoxol E.

Hemträdgården (1949), photo by May-Brith Ohman Nielsen. 
"Gangsters in your garden" was the caption of poster-like ads for "Diabol E, with DDT," from Elektrokjemiska A.B. ${ }^{71}$ Diabol E was not the only product on the Swedish market that followed the Norwegian pattern of giving morbid and devilish names to pesticides. Mortocid was marketed by an Upsala company in 1948 with the slogan "pure death," and Satan slug killer was advertised in the summer issues. ${ }^{72}$

The positive attention around DDT grew significantly in Sweden in the fall of 1948, when Paul Müller was announced as the Nobel Prize Laureate in Medicine/Physiology for his discovery of the insect-killing properties of DDT, a decade earlier. In Fruktodlaren the intensity of the massive pesticide advertising reached its first peak in the spring volume the following year: the first seven pages were full-page commercials for the following pesticide chemicals: Toxidol, Ewotox, Bladan, Parathion and Mataki - all Shell products ${ }^{73}$. Several patriotic lines can be found, but few compared with Norway, and slogans were mainly economic appeals like: "Save millions of apples," "the apple worms are raiding now." ${ }^{74}$

In the first issues of 1949 the Parathion-based product Bladan E 605 was marketed for the first time in Swedish gardeners' and fruit growers' magazines. The Bladan commercials were designed as copies of newspaper articles that claimed that Bladan was "the real sensation in the field of insect eradication" and that Bladan was proven to be better than DDT. ${ }^{75}$ The Toxidol $D D T$ and the Gesarol DDT ads answered their competitor's attack using the same means, printing fictive newspaper front pages in war typefaces that stated that the pest attacks were worse than ever. Ewotox commercials were also designed to resemble a newspaper front page, and Gesarol DDT reminded Swedish readers that they had a Nobel Prize Laureate working in their Geigy laboratory in Basel. ${ }^{76}$

The scale of the advertising, aggressiveness and competition between the many sellers and producers on the Swedish market increased in Fruktodlaren in 1950 and 1951. Many of these included "quotes" from "experts," "fruit growers" and "fruit doctors" as authorities to legitimise their claims, and quite often they added tables, chemical formulas, or other scientific forms of "evidence," such as listing the different products based on the same active ingredient with letters like Idocect E or Boxol X. A typical element in this Scandinavian marketing of the

\footnotetext{
${ }^{71} F R$ (1950), 41, inner cover.

72 See ads in $H E$ and FR through 1948 and 1949.

${ }^{73}$ See also FR (1949), vol. 3.

${ }^{74}$ FR (1950), 41, inner cover. Apple worm in Swedish translated from äppelblomstvivelen, Cydia Pomonelia.

${ }^{75}$ FR (1949), issue number 3, ads for Bladan in inner cover and the following issues. See also the huge ad for Bladan in the issues of 1950 and 1951.

${ }^{76} F R$ (1949), issue number 3 and the following, see especially the inner covers; see also FR (1950), 8, inner cover.
} 
products based on formulas invented, patented, owned or produced by international chemical companies, was to include letters from the international alphabet that were not in regular use in Swedish, Danish or Norwegian, like C, X, Q and Z to make the product name sound more technical, international, modern and reliable,${ }^{77}$ and perhaps add a bit of mystery.

Fruktordlaren started publishing systematic annual spray plans for members and readers in 1948. Like all spray plans in these magazines, this one was not designed to fight back major pest attacks in an identified locality, but to make gardeners adopt a general prescriptive system of precautionary spraying to "protect" their plants against a variety of insects. The plans were worked out by the state plant protection expertise at Statens Växtskyddanstalt. This first plan prescribed three DDT sprayings every year for apples and pear trees and one yearly DDT spraying on cherries and plums. In addition all gardeners were advised to spray their fruit trees with sulphur liquid and other chemicals in the cold season, a total of six sprayings on each fruit tree every year. These instructions were also repeated in the spray plan for $1949 .^{78}$

Towards the end of the 1948 season and in 1949 there were different voices in Fruktodlaren claiming that pest attacks increased in 1948 compared with earlier years. Some pesticide commercials also said the same, urging gardeners to buy more chemicals and spraying equipment before the next season. ${ }^{79}$ Some of the experts at the State Plant Protection Agency also raised their voices to advocate a more balanced view on the numerous products entering the market: maybe they were not as efficient as they claimed to be? ${ }^{80}$

The first article in Fruktodlaren about harm to bees was published early in 1950, written by an anonymous reader, under the heading "As little spraying as possible." But the editor stated that it "[is] our opinion that [the criticism] is not convincing." " However from 1951 onwards the magazine also printed articles about "useful insects" and about protecting bees from direct pesticide sprayings. ${ }^{82}$ Bureau Inspector at The Royal Fisheries Agency, L. Bruneau, also published an article in the magazine about how the toxic pesticides used in fruit production

\footnotetext{
77 See the entire volumes of $F R$ (1950 and 1951) and especially $F R$ (1950), 8, inner cover, 41, inner cover; FR (1951), 63, inner cover, 82ff.

78 FR (1948) 16f, FR (1949), 14ff. The plan for 1949 had additional comments from the plant protection experts.

79 FR (1948), issues 5-6. Advertisement for Toxidol, DDT, says "The year 1948 was a difficult year for many growers. The pests ravaged worse than ever - not least plant lice and winter moths" (transl.: frostfäriler) This ad was placed by the pharmaceutical company Ferrosan in Malmö, apparently a new seller or producer in the market, at least according to the ads in the columns of Fruktodlaren and Hemträdgården.

${ }^{80}$ Bror Tunblad, "Amerikanske erfarenheter av några nya insektsmedel," FR (1949), 48ff.

${ }^{81}$ Anonymous article, FR (1950), 63, and editorial "Vår uppfating," FR (1950), 41.

${ }^{82}$ Bror Tunblad, "Nyttoinsekter," FR (1951), 15; "Bina och Växtskyddsmedeln,” FR (1951), 50 (signed with initials).
} 
affected fresh water quality in lakes and killed fish. ${ }^{83} \mathrm{O}$. Stoy, one of the experts in Swedish fruit production, warned that there might be more damage from chemicals than from plant diseases to Swedish fruit and his report was published about new principles in fruit spraying. ${ }^{84}$ And although state plant protection experts, such as Bror Tunblad, continued to warn fruit growers about on-going attacks from the cherry fly, bark beetles and other species, ${ }^{85}$ and pesticide producers and sellers campaigned on behalf of their chemicals as ever before, one can detect a new, more balanced and cautious tone among some of the most profiled state plant protection experts. This is not reflected in the articles of Fruktodlaren, and was by no means given any serious editorial attention. However, it could be seen in the other Swedish gardening magazine for family gardeners, Hemträdgården.

Hemträdgarden published the same earlier ads for pesticides like sulphur acid and arsenic powder in 1945 and 1946 and published articles on how to eradicate moles, rowan moths and other pest animals typical of Northern Sweden and on how to carry out chemical "winter cleaning" of the garden. Still, this magazine had far less focus on pesticides in the first two postwar years. ${ }^{86}$ The first significant modern commercials for the new synthetic pesticides were a double-page Shell advertisement in the late autumn of 1946. Whether this lack of attention from the pesticide sellers was due to the fact that this magazine was fairly new as a publication with wide readership, and first really got going in the season of 1946, or whether the editors and state plant protection experts deliberately held back the pushing of the new synthetic pesticide technologies to these family gardeners who were not dedicated fruit growers like the readers of Fruktodlaren, is not clear. But from 1947 onwards Hemträdgarden certainly had the attention of the pesticide companies.

Hemträdgården and its readers appeared to have more complex garden ideals than the editors of the Norwegian magazine. The Swedish journal regularly presented themes showing a more holistic approach to gardening such as how to improve garden soil by making compost, understanding the valuable work of rain worms, and the need to cherish birds in the garden. ${ }^{87}$ These topics were virtually absent from the Norwegian journal, which almost exclusively promoted artificial fertilisers from the big Norwegian chemical companies as the way to good crops. And one might ask whether this positive interest in natural processes and wild birds also served to make the members of the Swedish gardening associations and the readers of the journal more cognisant of the possible risks of pesticides, when these concerns became more

${ }^{83}$ Inspector L. Bruneau, Kungliga Fiskeristyrelsen, "Frukttredsprutning och fiskedöd," FR (1951), 117.

${ }^{84}$ O. Stoy, "Borda ei sprutmedlens inverkning på fruktens utseende närmare undersökas?" FR (1951), $80 \mathrm{ff}$, and 140 .

85 See for instance "Se up med körsbærsglugan," FR (1951), 82ff, and 135ff.

${ }^{86} H E$ (1945), 7, inner cover, 22, 55; HE (1946), 17f, 45, 85f, 116.

87 See for instance $H E$ (1945), 45; various $H E$ issues in 1946; $H E$ (1950), 73ff; $H E$ (1952), 22 and $43 \mathrm{f}$. 
vocal ten years later. ${ }^{88}$

In early 1947, however, more or less the same ads that were published in Fruktodlaren could also be found in Hemträdgairden, at more or less the same time, and in constantly higher numbers through 1947, 1948 and 1949. Often these referred to company leaflets on how to use their different products. ${ }^{89}$ State plant protection experts warned against the same pest attacks in both journals and made the same recommendations as to which chemical measures to use, ${ }^{90}$ but with some modifications. In the first issues of Hemträdgarden in 1947, Bror Tunblad at the State Plant Protection Agency published an article with instructions on which chemical sprays gardeners should choose ahead of the coming season. He stated that it was worth trying out DDT products instead of the old petroleum-based products, but that one needed to conduct tests throughout the season in order to decide if it was wise to entirely get rid of the old remedies and switch to the new ones. ${ }^{91}$ Later the series of aggressive pesticide commercials, including extensive leaflets with company-produced spray plans, in the early spring of $1949^{92}$ caused a reaction from the state pesticide authorities, with Bror Tunblad at the forefront. In an unusually vigorous article, he attacked the intense and aggressive advertisements for pesticides and the giant proportion and increasing propaganda for pest chemicals. According to Tunblad, too many people now slavishly and uncritically obeyed the pesticide commercials:

They spray and dust whether it is necessary or not and with substances that we still know far too little about. How often have I heard, when I ask someone why they are so eager to do this or that spraying: No, they have certainly not experienced any pests, but one spraying can hardly do any harm! They will spray whatever the cost. And if you try to persuade them to refrain or warn them against using untested or too little-known substances, you will be accused of being too critical and halting progress. ${ }^{93}$

Tunblad himself presented the plant protection chemicals that gardeners should use for winter and spring-cleaning and, although embracing many of the new synthetic pesticides, his recommendations appeared quite moderate compared to the producers' own instructions to gardeners about the requirements and uses for their chemicals and the prescriptive "spray

\footnotetext{
88 See below.

89 See the different issues of $H E$ for these years, and especially the six-page inner cover commercials in the last issue of 1947, particularly for Shell products. $H E$ (1949), 46, the three pages of the inner cover front and back with the same series of newspaper-like ads for Shell, Gesarol, Toxidol and Boxol.

${ }^{90}$ See for instance $H E$ (1947), 53; $H E$ (1948), 47f, 70; $H E$ (1950), 73ff; $H E$ (1952), 86ff, on the rowan weevil by Bror Tunblad; $H E$ (1952), 92f, on rats and moles; $H E$ (1954), 38, on eradication of the cabbage fly larvae; A. Stenmark and Bror Tunblad, "Til äpplebladloppans bekämpning," HE (1952), 129.

${ }^{91}$ Bror Tunblad, "Infør valet av besprutningsmedel," HE (1947), volume 1.

92 See above.

${ }^{93}$ Bror Tunblad, "Reklameringen av växtskyddsmedel," HE (1949), $84 \mathrm{f}$.
} 
plans" they told Swedish gardeners to follow through the season. ${ }^{94}$ In 1950 the Swedish government appointed a commission to investigate and work out a control system for pesticide labelling, including instruction on their correct use, warnings on safety for users and rules to follow in order not to directly expose honeybees to the chemicals in open flowers. The commission was led by High Court Judge N. Gårde, with Bror Tunblad as a member. ${ }^{95}$ In 1949, 1950 and 1951 Hemträdgarden published articles about protecting bees from pesticide spraying, ${ }^{96}$ and in the spring of 1951 the magazine printed two articles by Bror Tunblad under the title "Useful insects in garden production," about more environmentally friendly ways of handling garden pests, replacing the most poisonous and harmful chemicals with methods for integrated plant protection to reduce the amount of excess chemicals down to a level of reasonable necessity. ${ }^{97}$ Gardeners should spray, Bror Tunblad explained in the early spring issue of Hemträdgarden in 1952, but many inexperienced gardeners sprayed too much and in the wrong way and neglected the basic hygiene of the garden. ${ }^{98}$

To conclude: the most widely read Swedish gardening magazine, Hemträdgairden, although it introduced and recommended schemes for chemical pesticide eradication and winter spraying of fruit trees, even testing out DDT products for some types of pests, still appeared far more moderate in the face of new synthetic pesticides. The magazine was also much more balanced in the way it presented pesticides to its readers via pesticide experts from the State Plant Protection Agency and their expert advice in Hemträdgarden was cautiously directed towards amateurs.

This was not least a result of the fact that some of these experts, including Bror Tunblad in particular, despite having recommended chemicals to solve most pest and disease problems in family gardens for several years, in 1952 apparently realised that excessive spraying was also a problem among gardeners. At this point Tunblad advocated integrated pest treatment and precautionary hygienic measures in gardens, and warned readers against excessive precautionary sprayings against non-existent pest problems. Hemträdgården also allowed some critical voices into their columns. The pesticide companies' own agents never appeared to have open access to the magazine's pages, nor a strong influence upon the editorial decisions as to what to present to the readers and from which perspectives, in contrast to Hagetidend.

Nonetheless, the readers of Hemträdgarden were regularly bombarded with pesticide

${ }^{94} H E$ (1949), 142ff. See also the extra six-page leaflet commercial for all Toxidol products that was included in the first issue of Hemträdgarden in 1950 and another 12-page leaflet with a spray plan for Toxidol products was included in the number 5 issue of 1950. A similar leaflet was distributed through the magazine in 1951,1952,1953, 1954 and an even bigger one in 1955.

${ }^{95} H E$ (1950), $22 f$.

${ }^{96} H E$ (1950), 57; $H E$ (1951), 83 and $85 f$.

${ }^{97} H E$ (1951), 10ff; Bror Tunblad, "Nyttoinsekter innom trädgårdsodlingen," HE (1951), $43 \mathrm{ff}$.

${ }^{98} H E$ (1952), $7 \mathrm{ff}$. 
commercials from numerous big producers as well as yearly instruction leaflets from the biggest companies. These probably functioned as a garden spray plan for family gardeners who bought the idea of including chemical pesticide spraying in their regular seasonal garden plan. The journal must have earned at least 80 percent of its income from ads for pesticide products. For the numerous readers, this was also a significant part of Hemträdgarden's message. The magazine of the gardeners' association was the main platform of communication between the organisation and its members. The massive pesticide commercials that often filled six pages inside the front and back cover of the spring and summer issues were certainly a significant part of the association's communication. This communication was further complicated by the fact that when Bror Tunblad published his new book on disease and pest control in Swedish gardens, in 1953, he did this in cooperation with the State Plant Protection Agency and Shell, the biggest commercial actor on the Swedish market with the highest number of ads in the gardening journals. ${ }^{99}$ This finding suggests that the link between the pesticide business and the state expert advisors and testers in Sweden obviously needs more research and also new source material.

Now, a so far open question concerns the effect of the new pesticide regulations that Sweden implemented in October 1953 as a result of the government initiative in 1950. These new regulations were worked out in detail as part of a Nordic cooperation in the field, where the national pesticide authorities in Sweden, Denmark, Norway and Finland shared their views and experience and set down details for the principles of labelling, including warnings of toxicity and hazards for bees. Much of this followed the Danish legislative reforms of 1948. ${ }^{100}$ This reform identified the product label and the label instruction as the main place for communication about correct use. It also introduced a classification system, where all pesticides in the national market should be classified into four categories, according to their acute toxicity for humans. This classification would be stated on the label, and only professional users would be allowed to buy the most potentially harmful of them, meaning that amateur gardeners could no longer themselves purchase the most poisonous chemicals, like Parathion and Lindan, but would need to hire a professional gardener or farmer to purchase and apply it for them in their gardens. Family gardeners could still purchase DDT products and a range of other chemicals and apply them themselves.

99 Bror Tunblad, Skadeinsekter på växande gröder och lagrade lantbruksprodukter (Stockholm: Svenska Shell i samarbete med Statens Växtskyddsanstalt, 1953). His first book from 1947 was on pests and pesticides in agriculture. Thore Lindfors and Bror Tunblad, Sjukdomar och skadedjur på våra lantbruksväxter (Stockholm: Lantbruksförbundet, 1947). His next book was on spraying fruit trees and berry bushes. Bror Tunblad, Besprutning av fruktträd och bärbusker (Stockholm: Lantbruksförbundet, 1955).

100 See below. 
In Sweden the Department for Public Health was given the authority to approve the labels, ${ }^{101}$ so that health concerns would guide the labelling. However, the authority to approve a product as a pesticide on the market still belonged to the State Plant Protection Agency. It was now forbidden to sell pesticides without the original package, on which the product number was printed so the health authorities could keep track of the products. Hemträdgarden commented on the new regulations like this, asking for more research and control for the benefit of the buyers and users of these products:

One might hope that inferior products, that are now sold in the "grey" market, will disappear from the market. We had hoped that the new registration would be combined with a continuous biological testing of all pesticides on the market. The need for such obligatory control that could provide consumers with some warranty, has repeatedly been explained to the authorities by, among others, the Swedish Pomological Society, and suggestions in this direction have also come from the State Plant Protection Agency. Although the authorities have chosen not to take this step all the way, the new regulations are no doubt a step in the right direction. ${ }^{102}$

Stricter regulations and testing to secure the consumers of pesticides their right to high quality products, appears to be the main objective of the Swedish Gardeners' Associations and their magazine. Concerns about long-term health effects or environmental harm were, however, not an explicit part of the consumer concern voiced by the Swedish Gardeners' Association in 1953.

\section{The Danish Gardening Association and the Magazine Haven}

In 1940 the Danish Gardening Society was an organisation consisting of three regional gardening associations, with roots going back to the middle of the nineteenth century. Their joint membership magazine Haven (The garden), was a well-established gardening magazine which included plentiful membership information as well as articles about different aspects of gardening. Haven was also sold in bookstores, kiosks and to subscribers who were not themselves members of the gardening associations. ${ }^{103}$ Haven was also the gardening magazine Danes could find in educational institutions and public libraries.

Compared with the Norwegian and Swedish magazines, the Danish magazine had relatively more focus on garden design and on decorative plants. In this period the typical Danish

101 This process is currently being investigated by the author and is expected to be published under the title "Constructing the concept of poison in Scandinavian post-war pesticide administration, 19491955."

102 "Ny lag reglerar handeln med växtskyddsmedel," HE (1953), 173 (signed by “Y,” meaning editorial).

${ }^{103}$ Later Det Kongelige Danske Haveselskab (The Royal Danish Gardening Society) was also included and the four member associations took this name as theirs after a legal merge in 2007. 
garden was a farmer's family garden (landbohaven), a suburban garden or the "colony" garden (scherbergärten, allotment garden). They were flat like Denmark itself, and they usually had excellent conditions for kitchen, fruit and flower gardening. Denmark was mainly an agricultural country, with a significant export of agricultural products, mainly grain, dairy products and pork. Food shortage was never a national issue, not even in the years of German occupation 1940-1945. However, fruit, berries and vegetables were at the time more garden products than agricultural products in Denmark. And Haven had an implicit, but vocal tone claiming that gardening was not agriculture, but something entirely different. There was also a much more positive interest in decorative trees in the Danish magazine, a country with mainly open fields and no natural forests, than in the magazines of the forested countries Sweden and Norway. Likewise Haven presented birds and other wildlife, like squirrels and hares, as a natural and welcome part of the garden, where they could find refuge from the ever more efficient Danish farmers with their rising number of tractors. ${ }^{104}$ In the Norwegian magazine, the general tone was that birds and other animals should stay in the forest where they belonged.

According to the editors of Haven, the Danish garden should be a place to retreat and relax from the stress of professional life. Gardening was a hobby for dedicated garden lovers, a place to be creative, not effective. The members and readers of Haven wanted to learn more about plants and gardening and ideas for garden design. But on the whole they refused to be told what to do, especially by professionals. Haven published quite a few examples of strong reactions from members after talks or articles by professional gardeners, about how to make gardening more time-efficient or "rational." The critics argued that professional gardeners had no business imposing their ideas about work, time or gardening upon amateurs. It was their own garden, their own pastime and their own way of life. This line of controversy can be observed in the debate about "wasted time in gardens." 105 However, as we shall see, the instructions on pesticides were exempt from this general picture and the Danish gardening association took great care to promote pesticide technology and practices in local garden clubs and neighbourhoods through a system of peers. ${ }^{106}$ The pesticide ads in Haven also adapted to this cultural tradition by featuring drawings of cheerful Danish gardeners in hygge with their neighbours and their pipes, spraying their gardens while happy housewives in attractive outfits spray-cleaned their apple trees as if it was their favourite pastime.

${ }^{104}$ See for instance HA (1942), 107; HA (1942), 107; HA (1951), 10, 106; HA (1956), 22, 23; HA (1942), 107.

${ }^{105}$ H. Mosegaard, "Spiltid i haver," [Wasted Time in Gardens] HA (1951), $26 f$.

${ }^{106}$ See below. The experienced pesticide sprayer who carried out sprayings within or for a local garden club or in a local area, would be called the "spray-man," like a milkman or a postman, someone who semi-belonged to the neighbourhood with a special function, delivering a special service there on a regular basis, not an expert gardener telling people what to do. 


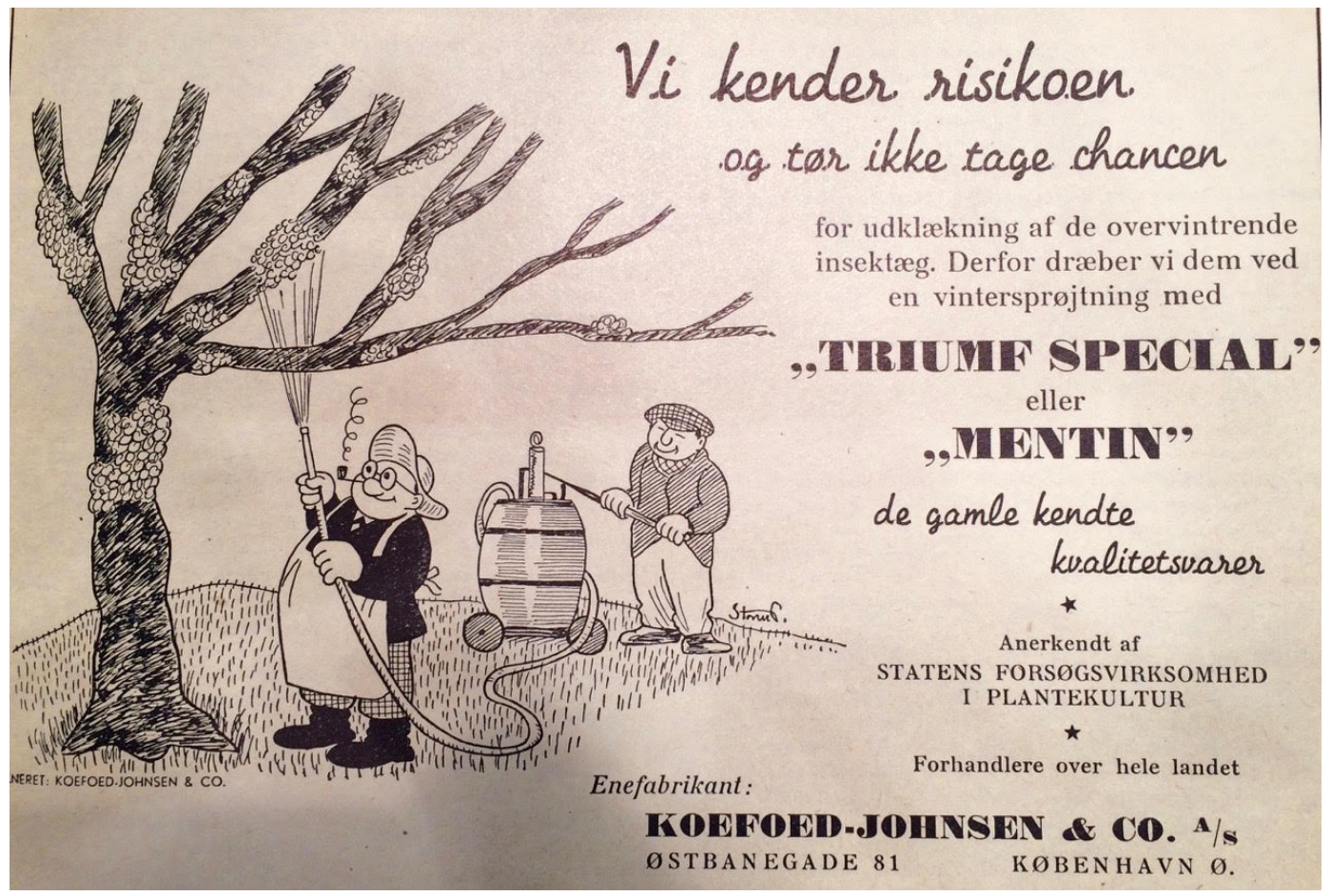

Figure 4 - Danish cosy spraying ad.

Haven presented Danish gardeners as laidback feel-good sprayers who attended their gardens under the happy influence of peers and neighbours, not professionals. The imagery was aligned with established Danish self-images of cosiness and collective "we."

Haven (1949), photo by May-Brith Ohman Nielsen.

With this exception, Haven displayed the same attention to garden professionalism and to garden and plant experts as the Norwegian magazine, but the voices of experts dominated the columns to a lesser degree in the years up to 1948. During the years of war and German occupation, Haven encouraged readers to grow a kitchen garden and raise their level of selfsufficiency, growing more fruit and eating more Danish products, but not forgetting flowers, because flowers cheered people up in dark times. ${ }^{107}$

The magazine offered massive advice on this, and both the garden association and the readers of Haven raised their voices to provide more instruction on activities like garden exhibitions, garden courses and classes to increase the yield of home gardening. ${ }^{108}$ But Danish editors rarely urged home gardeners to join in national efforts to intensify food production, as in Norway.

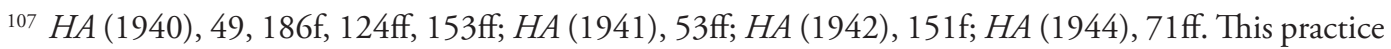
also continued in the face of a new economic crisis in 1951, see $H A$ (1951), 3.

${ }_{108} H A(1940), 146 f$. 
Haven also paid regular attention to plant problems and pest attacks, and editorial attention to these matters grew through the war years. The magazine printed one article each month presenting the usual pest problems of that part of the season, and the chemical remedies to fight them. ${ }^{109}$ The main plant protection expert used by Haven in the war years was the plant pathologist Anne Weber. She worked at the State Institute for Plant Pathology and had published the acclaimed volume Plantesygdomme (Plant diseases) on plant protection in 1940, together with Ernst Gram. ${ }^{110}$ The book was addressed to fruit growers, professional gardeners and garden owners alike, and featured colourful instructive drawings, as well as photos, of sick plants and plants suffering from pest attacks, so that gardeners could easily identify the nature of the problems in their garden.

From 1941 onwards, Haven paid much more attention to pest control and to increasing family gardeners' awareness of pest problems. The reason given for this intensified focus was the wartime shortage of nicotine and other substances traditionally used for pest control. Both Danish authorities and the plant protection experts in Haven urged the owners of small gardens to pay close attention to possible pest and disease problems, and to use as little of the scarce chemicals as they could to make them more available for agriculture. They were also instructed to keep future problems in check by using petroleum-based products to "clean" the trees from hibernating insect eggs in the winter and not to overdo the spraying and damage the trees. ${ }^{111}$ According to the leading plant protection expert Anne Weber,

It will be of great importance to kill as many pests as possible before the buds break in spring. Among these are aphids, apple blossom leaf fleas, scale, spinner moth larvae, bud moths, winter moths, apple tics and fruit tree spider mites that can be killed by spraying with the best winter and spring tar oil products.

At present, everyone, with the aid of a magnifying glass, can form their own impression of how many brown shield lice, long oval shaped leaf flea eggs, shuttle shaped yellow leaf flee eggs, or round red spider aphid eggs there are on their trees. Most of these eggs sit at the base of the fruit buds and spider mite eggs are also often found below the angle of the branches. Wherever one finds these eggs, or knows that these animals were present last season, one should spray with winter and spring tar oil this winter season. ${ }^{12}$

\footnotetext{
109 See HA Spring, Summer and Autumn, 1940.

${ }^{110}$ Ernst Gram and Anne Weber, Plantesygdomme. For frugtavlere, gartnere og haveejere (Copenhagen: Emil Wienes Bogforlag, 1940).

111 "Sygdomsbekjempelse i Smaahaver 1941. 315. Meddelelse fra statens forsøgsvirksomhed i plantekultur," $H A$ (1941), 86ff.

${ }^{112} H A$ (1941), 42f. Weber was trained as a gardener, one of the first professional female gardeners in Scandinavia. However, she spent her entire professional life working as a plant pathologist at The State Plant Protection test facilities. Contrary to most Norwegian experts, she was not an entomologist. Her focus was more on protecting plants than on killing insects.
} 
This quote is typical of the advice given to Danish home gardeners about pesticide technology at the time, and Anne Weber here sets this standard. Gardeners should examine their plants carefully and through a magnifying glass, detect and define what kind of pests they found and spray them with traditional oil-based anti-pest products in the winter season. For the summer season the main advice from Weber was to pay close attention to the plants, be alert to any pests or diseases, and immediately cut off and burn any disease- or pest-affected plant parts. In June 1941 she explicitly advised home gardeners that in most cases they could, quite easily, collect harmful insects from the leaves or buds by picking them off with their hands in the morning and killing them in a costless way, thereby saving sparsely available chemicals for situations where these mechanical methods were insufficient. ${ }^{113}$ Among the latter cases, soil-living pests and root diseases were not so easy to detect at an early stage, or to get rid of by manually removing the attacked organic material. ${ }^{114}$ Both Weber and other authorities reminded home gardeners that birds ate many harmful insects and insect eggs and that putting up nesting boxes in the garden could be very useful and enjoyable. ${ }^{115}$ By 1941 the recommended sprayings through the seasons were four times for apples and cherries and three times for berries, with additional sprayings if there were pest attacks outside the regularly scheduled spray times. ${ }^{116}$

Danish authorities and agricultural seminars now offered new courses to educate both professional gardeners and eager amateur gardeners and fruit growers in the use of "poisonous pesticides" like lead arsenate and nicotine, and in the cyanide smoking of greenhouses. The courses were announced in Haven. ${ }^{17}$ Haven also printed official instructions on how to fight pest and diseases in small gardens, ${ }^{118}$ and they launched a new annual "disease calendar" in the issues throughout the year in the form of articles on how to fight "the pests of the month." 119 The level of editorial attention and space dedicated to these themes, as well as the recommendations and advice, followed this same pattern through 1942, 1943 and $1944 .{ }^{120}$

Anne Weber also wrote articles in Haven alerting readers to the increasing amount of spray damage to fruit trees, berry bushes, decorative plants and lawns that could be observed in gardens in 1943. In 1944 she again warned gardeners to use the available remedies, like lead arsenate, nicotine, sublimate, sulphur and Bordeaux Liquid sparingly, due to shortages of

\footnotetext{
113 “Bekæmpelse af plantesygdomme i Juni," HA (1941), 87ff.

${ }_{114} H A, 1941,1942$ and 1943, articles in the monthly disease calendar, by Anne Weber, see for instance $1941,87$.

115 "Sygdomsbekjempelse i Smaahaver 1941. 315. Meddelelse fra statens forsøgsvirksomhed i plantekultur," $H A$ (1941), 86ff.

${ }^{116} H A(1941), 57 f f$.

117 "Giftkursus" [poison course], HA (1941), 46.

${ }^{118} H A(1941), 86 f$.

${ }^{119} H A$ (1941), 86ff, 108ff, 127ff, 140ff; $H A$ (1942), 60ff, $123 \mathrm{ff}$.

${ }^{120}$ See for instance $H A$ (1944), $56 \mathrm{f}$ and references on 57.
} 
supply, and with great care for their toxicity. ${ }^{121}$

It is interesting to note that the words "poison," "poisonous," "risk" and "careful" were much more present in the texts in Haven than in the Norwegian magazine. These words were also more present in the official communication from the Danish State Test Program for Plant Cultures. They both reminded readers about acute toxicity risks and the need to be careful when mixing and applying the chemicals and the need to protect bees and plants for immediate consumption. This public institution considered that the average Danish garden, especially in the many colony garden communities, was a mixed garden, where different crops and plants were grown close to each other and had different harvesting and consumption times. ${ }^{122}$ The new Danish legislation on poisonous substances passed in 1948, was also a result of this greater public concern, raised by a series of accidents in previous years. The new legislation also impacted the discourse and raised awareness among the consumers of pesticides about the acute toxicity hazards of these products. The legislation introduced a system of categorisation of poison into four groups, mandatory labelling with skull and crossbones for the strongest poisons and warnings to avoid killing bees during application.

Haven presented the first article on chemical pest control causing problems for bees in the summer of 1944 with reports of 150 hives that had died after the spraying of fruit trees, vegetables or other agricultural plants. The warnings not to spray on open flowers visited by bees were repeated every year and in most of the instructions. However, the claims about which spray practices did in fact harm bees varied considerably from expert to expert. ${ }^{123}$

Weber also urged readers to limit their use of chemicals for the sake of the plants, useful insects and other animals. This line by no means rejected chemicals. The Danish test program was the most extensive in Scandinavia and Danish experts wanted to make sure that the chemicals recommended really solved pest problems.

However, from 1944 onwards another trend can be observed in the Danish gardening magazine. This summer the first Danish tests with the Swiss Gesarol DDT powder against pests were published in Haven by the State Test Institution for Plant Culture (Statens forsøgsvirksomhed for plantekultur). The report published for readers was enthusiastic: Gesarol powder "[has] shown an excellent effect on a series of pests (...) and the effects have remained for a month

\footnotetext{
${ }^{121} H A$ (1943), 116ff; (1944), $56 f$.

122 See for instance $H A$ (1944), 93f; "Sprøjtning af æble- og pæretrær," HA (1948), 53ff; "Meddelelse fra Statens Forsøgsvirksomhed i Plantecultur, 122," HA (1948), 116f, 118f; "Systemiske insekticider, " HA (1952); HA (1953), 91. The Danish words are "gift," "giftig" and "forsigtig"/ "med omhu."

${ }^{123} H A$ (1944), 92. This report is signed by Ole Hammer, who recommended using the new product Gesarol that is "harmless to bees." See the issues throughout the season.
} 
or more." 124 The 1944 report on rising numbers of dead beehives also recommended Gesarol as a substitute for poisonous traditional substances, claiming that DDT was not harmful for bees. ${ }^{125}$

Spraying of pesticides had been on the rise in Denmark since 1942, and in the first peace summer of 1945, when more chemicals were available again, the appeals to spray became more frequent in Haven. In 1946 there was a dramatic change in content, tone and perspective compared to the wartime years. The supply of chemicals was no longer scarce and Haven abandoned economic arguments and appeals to self-supply, turning to moral arguments for the use of pesticide technologies in Danish gardens:

How often does one not get a strong urge to walk around and shake those gardeners really hard, who do not attend to their fruit trees properly with spraying, not least when one, right across the hedge, can observe the results and hear the fruit trees whining over scab and cancer and all their misery. ${ }^{126}$

Unlike in the Norwegian and Swedish magazines where this pressure was raised by presenting elevated experts who pointed their fingers at the amateur gardener, Haven presented this as enlightened reasoning in the mind of the home gardener himself. In the annual article series titled "What did we learn about disease control in fruit gardens in 1947?" with follow-ups in 1948 and 1949, the Danish plant protection experts seemingly sat down as a friend to guide a session of self-reflection with the home gardener, in the form of a collective Danish "we" who were all in the same boat. This genre was well developed and familiar to gardeners, especially in collective gardening groups like the colony and allotment societies. ${ }^{127}$ Haven envisaged a nationwide project of nation building through cultivating Danish gardens.

The person who works with plants will never be wise enough, but must strive to be as wise as possible. A help in these matters is to reflect, after the plant growth of the season is over, on what really seemed to work in the past year. Then, there is a chance that one might be more successful in the fight against diseases and do other things that help the plants. ${ }^{128}$

The Danish "we" followed the expert advice: there was no use spraying after the fruit problems had occurred, because the chemicals would then have to be so strong that the plant would be damaged. The experienced gardener and fruit grower assessed their actions after the fruit was harvested by asking: "What could I have done better?" Then they would start planning and

124 "Forsøg med Gesarol-pudder mod Skadedyr. 364. Meddelelse fra Statens forsøgsvirksomhed i Plantekultur," HA (1944), 92.

125 HA (1944), 92.

126 "Sprøjting af frugttræer," HA (1946), 83f.

127 Ohman Nielsen, Små paradiser.

${ }^{128} H A$ (1947), 89ff. See also same type of articles the following years. 
preparing for next year's disease control. After this reflection Danish gardeners were open to instructions: check your trees and bushes thoroughly with a magnifying glass. Make notes of what you find, and if you cannot manage the spray plan for next year alone, the local gardening consultant of the gardening association will help you plan and carry it out. ${ }^{129}$ In this way, prescriptive pesticide technologies were pushed upon gardening families as if they were the ideas and will of the gardeners themselves.

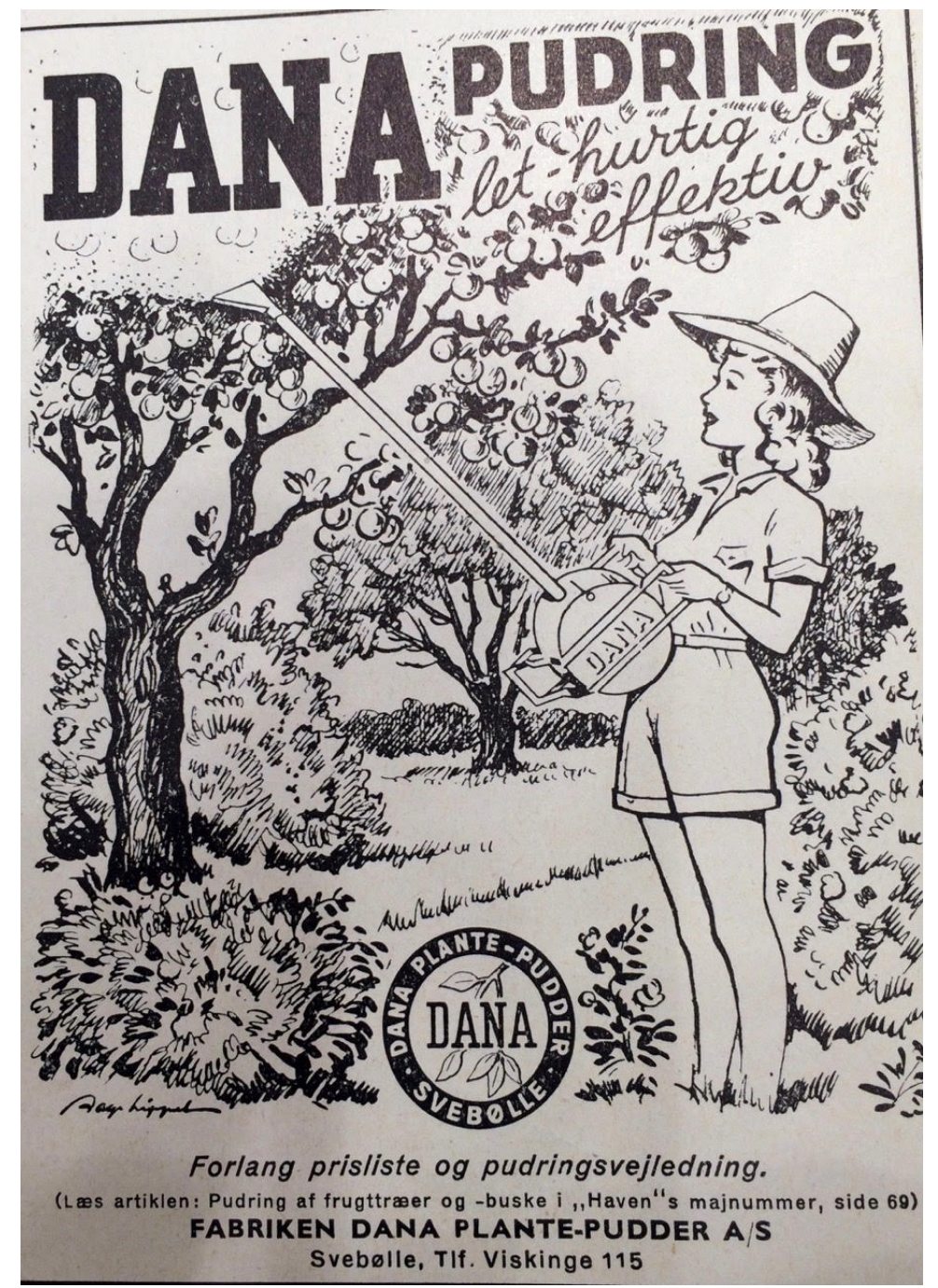

Figure 5 - Danish spray glamour ad.

Pesticide promoters in Haven also appealed to middle class women gardeners by presenting spraying as effortless, clean, chic and Danish.

Haven (1949), photo by May-Brith Ohman Nielsen.

${ }^{129} H A(1947), 89 f f$. 
From 1945 onwards some local garden clubs within the Danish Garden Association organised so-called "spray circles." This form of organisation took off in the following years. The members either bought spraying equipment together and let the more skilled gardeners do the spray job in all the gardens for some compensation, or they hired a professional gardener to spray the members' gardens. In some areas they also strongly encouraged their neighbours to join the spray circle. This way, gardeners did not have to carry out this "uncomfortable and messy" work themselves. Nor did they have to invest in their own spraying equipment or educate themselves about what products to use, when and how. This was the best way for gardeners and neighbourhoods all over Denmark to take care of their fruit trees, according to the magazine's experts. The local garden clubs should take care of the spray circles, and reluctant gardeners should leave the thinking and the execution to the collective of peers.

According to Haven it was far cheaper and better to hire a serious professional with a proper motorcar tank and engine-spraying equipment, than to use the old bike trailer spray cans with manual pumps that some clubs had. By joining forces all over the country, gardeners could raise the standard, not just for the maintenance of fruit trees, but also as consumers of spray services. ${ }^{130}$ The Norwegian Gardening Association, its local clubs and colony garden societies, and many urban neighbourhoods in Norway also organised spray circles in this way from 1946 onwards. ${ }^{131}$

In 1947 and 1948 Haven instructed its members to carry out a growing number of spring and summer sprayings and winter spray cleanings in their gardens. By 1948, 103 "spray-men" who had completed the two-week intensive courses in spraying run by the Danish Gardening Association, and a one-day course at county level, were employed on a regular basis and full time in the nine counties closest to the capital Copenhagen. Most of these spray-men had bike trailer barrel spray equipment. But 32 of them had bigger and more advanced motorised engine spray trolleys pulled by cars or motorbikes. ${ }^{132}$ This organisation made a big difference Haven told Danish gardeners, and raised social pressure by playing on both local pride and personal ethics: when one travelled across the country and crossed from one parish where the collective spray work was well established and into a parish where there was no such organisation, the traveller could clearly observe, from the local fruit gardens, which parish had spray equipment and which did not. ${ }^{133}$ Haven also encouraged social pressure by pointing their finger at urban and suburban gardeners who sabotaged the joint efforts of pest and disease eradication by not spraying their property. This was the tone:

Unfortunately, there will always be some gardeners who do not understand the

\footnotetext{
130 "Sprøjting af frugttræer," $H A$ (1946), 83f.

131 Ohman Nielsen, Små paradiser, 181ff, 206ff.

${ }^{132} H A(1948), 116 f f$.

${ }^{133} H A(1948), 116 f f$.
} 


\begin{abstract}
importance of carrying out the spraying and completely neglect to fight the pests and diseases that plague their gardens, arguing that they still get a satisfactory harvest and have saved themselves a troublesome task. That neighbours in this category are not held in high regard by the conscientious gardener, who does everything to protect his plants from all pests and disease, is obvious, but it can often be hard to convince the negligent that he would really achieve something by carrying out the necessary sprayings. The fact that the vast majority of garden owners want to carry out the sprayings, to achieve the best and biggest harvest, is evident by the enormous demand for spray products and spraying equipment in the last ten years. ${ }^{134}$
\end{abstract}

From 1946 onwards more people were engaged by Haven as experts on plant protection and especially on the topic of spraying. The experts now recommended a higher number of sprayings, as well as precautionary sprayings, and with a wider range of substances that were now available. Among these was DDT with the products Gesarol and Idosect. However, most expert advisors recommended the traditional chemicals because they had proven their effect in practice and in the test performed by the Danish Plant Test Institute. In the years 19451948, there was no significant enthusiastic editorial presentation of either DDT or the Lindan product Hexa 666, and there was far less general recommendation of DDT to the readers of Haven, as compared with the instructions given to Norwegian gardeners. ${ }^{135}$

The new American plant hormone chemicals were presented in Haven 1948, and in a positive way. ${ }^{136}$ The anti-weed hormone products counted for a significant section of the ads from 1950 onwards. Others were growth hormone products like Rootone and Transplantone, to promote roots on cuttings for propagation; Fruitone B, to speed up the development of fruit on tomatoes and beans, make them bigger and even remove the seeds from the tomato if the dose was doubled; Fruitone $O E$ against fruit fall; and Weedone 2,4-D to kill weeds in lawns. These were marketed in large advertisements from 1949 on. Haven wrote favourably about these chemicals, but said that they were not well proven yet, and suggested that gardeners test for themselves by leaving a few plants unsprayed. ${ }^{137}$

In 1948 there were no advertisements for pesticides in Haven at all, and this continued with a few exceptions until the spring of 1949. This is in striking contrast to Norsk Hagetidend, and also to Hemträdgairden. ${ }^{138}$ The reason for this lack of pesticide ads is not obvious, but it relates to technicalities rather than conviction and should not be misinterpreted. The new

\footnotetext{
${ }^{134} H A(1948), 118 f f$.

135 On the Norwegian gardening magazine, see above. On Haven, see HA (1947), 89f; (1948), 24ff, 53f, 65ff, 86f. The latter, in the series of pest calendar by Anna Weber has a few more recommendations of DDT. $H A$ (1948), 101f, 116ff, 118ff, 120ff, 167ff.

136 "Ukrudtbekjempelse med hormonpreparater," HA (1948), $101 \mathrm{f}$.

137 "Hormonsprøyting," HA (1952).

138 See above.
} 
Danish legislation on toxic substances of 1948 required new categorisation and labelling of all poisonous products on sale. The new labels needed approval from both health and pesticide authorities before they could be marketed. From this point on, all strong pesticides sold in Denmark had to be labelled with the skull and crossbones and "GIFT" (poison in Danish), in capital letters to avoid the rising numbers of home accidents caused by these chemicals. ${ }^{139}$ This process delayed the right to advertise the products until the labelling had been approved. This by no means meant that the Danish gardening association was less enthusiastic about pesticides. Nonetheless, Haven must have really felt the economic impact of losing its major income from pesticide ads for more than a year.

Danish gardeners were still urged by Haven to spray, and to attend to their chemical cupboard and "stay prepared with their spray products" throughout the season. ${ }^{140}$ Danish experts also strongly recommended a "general cleaning" of the garden with chemicals every year. ${ }^{141}$

From 1948 onwards, Haven regularly published the communications from the state test program for plant cultures and their recommendations for sprayings against different plant problems. In their advice on the spraying of apples and pear trees, they recommended DDT, but to a very limited extent. ${ }^{142}$ The same holds for the recommendations from Anne Weber and other experts on the subject. These relatively careful recommendations were also kept up in the spring and summer of 1949. ${ }^{143}$ Danish gardeners were now even discouraged from carrying out the traditional winter sprayings with tar oil on their fruit trees, and advised to only apply tar oil on fruit trees that had been neglected and were unhealthy. ${ }^{144}$ Readers were also warned against damage to garden plants caused by incorrect use of sprays and powders. ${ }^{145}$

However, from the summer of 1949 onwards the commercial ads for different pesticides in Haven really took off, both in size and in numbers. But there were, until the spring of 1950, still very few references to DDT in the ads or recommendations of DDT in the editorial

\footnotetext{
139 P. Bonnevie et al, Betenkning om revision af lov om gifte og andre for sundheden farlige stoffer m.v. (København: Møllers, 1959).

140 See for example $H A$ (1948), $120 f$.

141 "Efteraarsrengøring," "Frugthavens sommersprøitning," HA (1946); HA (1947), 21f. The term often used is "hovedrengjøring" and refers to the extensive winter cleaning with tar oil. A few modifications to this instruction on winter cleaning can be heard from some of the experts, like in $H A$ (1949), 21f, whose advice is only to winter-spray neglected fruit trees and not healthy ones.

142 “Sprøjtning av Æble- og Pæretrær. 122. Meddelelse fra Statens Forsøgsvirksomhed i Plantekultur," $H A(1948), 53 \mathrm{f}$.

${ }^{143} H A$ (1948), 24f, 86f, 116ff, 118ff, 120f, 167ff; $H A$ (1949), 53, 69f, $73 f$.

${ }^{144} H A$ (1949), $21 \mathrm{f}$.

145 Ibid., $87 f$.
} 
material compared with the Norwegian and the Swedish magazines. ${ }^{146}$

Although pesticide producers now advertised products that they claimed killed "all pests," like Cryocid, figuring 11 categories of insects in their ads, and Kill-it Universal, with the slogan "fight it all," and promoted this product against pests, red spider mites, scab and mildew, Haven advised Danish gardeners to be critical of exaggerated promises. Conscientious gardeners should follow the advice of the State Plant Pathology test program in their choice of pesticides, because the program was qualified to assess the cost and benefits of applying chemicals. This assessment was a problem for amateurs to take on by themselves because this calculation, made incorrectly, was exactly what kept ignorant gardeners from spraying.

One can only hope, that one beautiful day, among all the many new products, the exact product will appear that answers the dream of all spraying gardeners: the Universal remedy, that kills all fungi, disease and pests while not being poisonous, because it is the considerable toxicity of many of the products in use, that keeps many from spraying. (...)

This was the high hope for the new DDT and 666 products. But unfortunately these chemicals did not show as good effects as expected, so one again and again has to turn to nicotine and arsenic compounds. This should, however, not deter customers if they are aware of their toxicity and are cautious about their use and storage. This does not mean that the DDT and 666 products are without effects; in most cases they have proven to be useful under pest attacks when earlier one was without any effective means. ${ }^{147}$

From 1948 on the magazine expected every conscientious gardener to have a chemical cupboard, and to regard this as an essential tool for their gardening, and therefore for the gardening association to address. How many gardeners had the necessary chemicals at home at the exact time when the chemicals should have been applied, Haven asked its members in the summer of 1948. Only a tiny percentage, they believed, and explained the consequences. This was exactly why so many Danish gardeners were now annoyed at seeing worm-eaten fruit and other destroyed garden plants and products, because they had not sprayed at the right time. These gardeners did not have the chemicals at home on the day they should have sprayed or powdered. "Let's hope that this costly experience will make them promise themselves that this will not happen next year. Next year there will be order in the chemical cupboard and system in the sprayings." ${ }^{148}$ The necessary chemicals to keep in store were, according to Haven, blue vitriol, lime sulphur, lead arsenate and nicotine 80 percent. ${ }^{149}$

146 See for instance $H A$ (1949), 95, for the new Danish powder DANA presented by a woman with a duster. The July issue has multiple ads for Mindol, Acme powder blower and anti-weed plant hormones. $H A$ (1949), 112 presents different Bladan products to readers. See also the subsequent issues.

${ }^{147} H A(1948), 118 \mathrm{ff}$.

148 "The chemical cupboard. Be prepared with the spray chemicals," (transl.) HA (1948), $120 \mathrm{f}$.

149 HA (1948), $120 f$. 


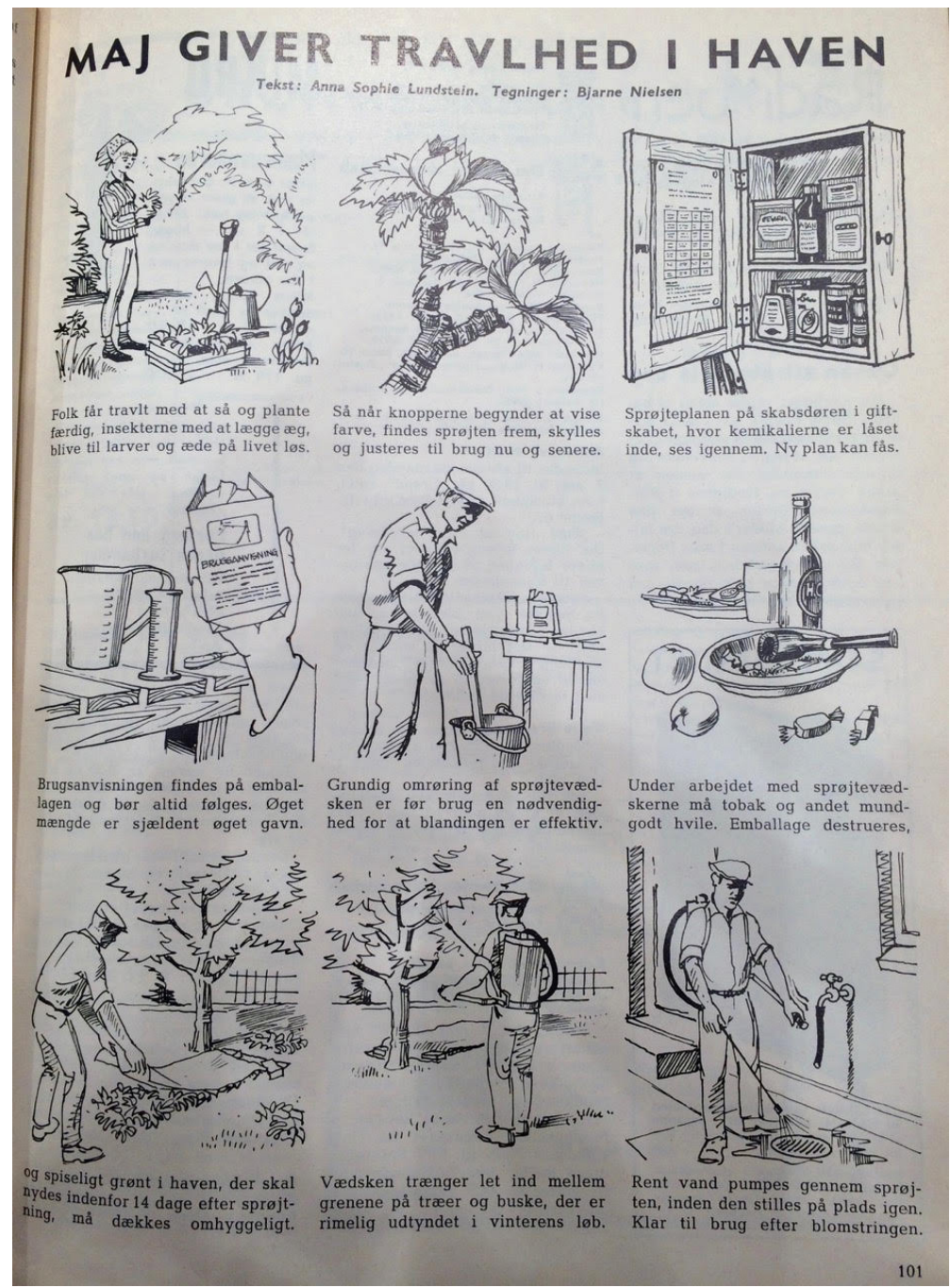

Figure 6 - Danish cartoon with poison cupboard.

Cartoons in Haven told gardeners how to prepare for the month of May. In May people were busy planting, the insects were busy laying eggs and their larvae were busy eating away on the plants. The moment the buds break gardeners should turn to their properly prepared poison cupboard, with the seasonal spray plan pinned on the door. They should mix the chemicals carefully according to the instructions, refrain from eating, drinking and smoking, spray the fruit trees and clean the equipment afterwards.

Haven (1948), photo by May-Brith Ohman Nielsen.

Later the same year Haven and the pesticide experts explained why they did not applaud the new pesticides as the universal solutions they promised to be. There were still no really affordable products against sucking insects like leaf lice, tics and "the countless mites that appeared last year." All the chemicals were, like nicotine, expensive to use in the concentration that made them truly effective. 
We appreciate both DDT, 666 etc.; but we keep hoping that these remedies, with the help of their mass consumption, will come down to a price level where one does not have to think twice before one responds to the attack with the spray or the powder blower. ${ }^{150}$

For mining larvae, nothing could compare with lead arsenate in price, concluded the Danish pesticide experts in Haven in the fall of $1948 .{ }^{151}$

The rather cautious line held by the plant protection experts of Haven was probably also influenced by the results of the testing of DDT at the State Test Station for Plant Cultures in 1948 and 1949. Anna Weber summed up the tendency and the paradox in 1950 Horticultura: never before had there been more effective insecticides on the market. Never before had the population of harmful insects been so numerous. And never before had these bugs attacked so many plants. Why? Her answer was 1) Monocultures. 2) Disturbance of the biological balance in nature because predator insects, like ladybugs, were being killed in higher numbers than the pest insects and the harmful insect population they feed on was now increasing undeterred. 3) Many pest insects had become immune to the chemicals used to eradicate them, she claimed. A certain predator Reduviidae could during its lifetime manage to kill 5000 spider mites. But the Reduviidae itself was easily killed by poison, she explained:

In one single test case the mites procreated so intensively after the last spraying (17th August), that the attack on the date of the counting, 8th October, was worse in all the sprayed test squares than in any of the untreated ones. ${ }^{152}$

This statement, not even printed in Haven but in the smaller publication Horticultura, was essentially the last message Weber got across to Danish gardeners through gardening magazines for a long time. 1949-50 appears to be a turning point in the advice and instructions given to the readers of Haven. However, some companies adapted to this criticism in their ads. For example, Midol published its own spray plan in 1951 and told gardeners that this chemical was without DDT and did not harm ladybugs or other useful insects. ${ }^{153}$ The overall impression is very clear. The big producers and sellers took up the fight for positive attention in Haven.

From 1949 up to 1955 many leading agriculture and plant experts in Denmark took part in an extensive educational program offering study trips to America and US agriculture institutions as part of the Marshall Plan. ${ }^{154}$ This exchange program seems to have fostered a new generation of pesticide experts and a new generation of advisors for the Danish Gardening Association.

\footnotetext{
${ }^{150}$ Ibid., $168 \mathrm{f}$.

151 Ibid.

152 See Anne Weber's article in Horticultura 5 (1950).

153 HA (1951), 63f.

154 Sissel Bjerrum Fossat, Den lille pige med iskagen. Marshallplan, produktivitet og amerikanisering (Odense: Syddansk Universitetsforlag, 2015).
} 
New names appear as signatures under the pesticide articles in Haven. ${ }^{155}$

One example of this new tone is Henrik Nielsen who in the summer of 1949 urged Danish family gardeners to cover their fruit trees with chemicals as soon as possible.

From the moment you can observe new leaves and shoots on the trees, the green parts are exposed to attacks from both fungi infections and pests, and it is time to start the summer sprayings. Fighting fungi diseases is done using precautionary methods by continuously keeping the new sprouting leaves and shoots covered with chemicals that prevent the fungi contaminants from germinating. Consequently, the spraying must be done with shorter intervals in the springtime when the new growth is faster, than later in the summer. ${ }^{156}$

In the columns of Haven, there almost seems to be a coordinated commercial counter-attack on the careful line and warnings of plant protection experts like Weber. From February 1950 and onwards numerous new products were promoted in huge ads printed in almost every issue. This new flow of substantial pesticide promotions, not only poured pesticide propaganda for the new synthetic products over readers and association members; it also obviously threw a lot of money at the magazine. Very soon the editors must have realised that the pesticide ads were the most profitable income for Haven. Among the products now marketed in almost every issue were Triumf Special, AKIDAN 49, IDOSECT with DDT and 666, IDOSECT SPECIAL, Cryocid, Sectos 7, a parathion product presented as a universal remedy against all insects, Kill-it with 33,3 percent DDT and Kill-it Universal, with DDT and other active poisons. ${ }^{157}$

The major turning point in the pushing of prescriptive pesticide technologies can be observed in the advice given by the experts of Haven to Danish gardeners in 1951. A national emergency was declared because of fears of an attack by San José scale, which had caused massive pest problems in California and had spread to other countries. The Danish authorities set out a series of strict special measures against possible San José scale invasion, and these were published as a declaration in Haven. The government organised a systematic acquisition and storing of pesticides around the country in case of a local outbreak. Among the pesticides stored were many of the newer chemicals, including DDT. ${ }^{158}$

From 1951 on, Haven published the spray-plans designed by the State Test Program in Plant Cultures. From this point on this plan became gradually more like the Norwegian one,

\footnotetext{
155 The connection between the Marshall Plan and pesticide policy in Norway and Denmark also needs more research.

${ }^{156}$ Henrik Nielsen, "Sommersprøyting af frugttræer," HA (1949), 53. See also the report in Haven from the spray course January 31 - February 12, 1949, held by the cooperation organisations.

157 HA (1950), 31, 50, 82, 98. See also the following issues and the following seasons. The ads usually ran from the spring issue until the September issue when the spraying season was over.

${ }^{158} H A(1951), 58$.
} 
although not quite as extreme. ${ }^{159}$ Haven also warmly recommended the two major books on plant disease, pests and pesticides in fruit, berries and vegetables in gardens by the leading Norwegian experts, the state mycologist and the state entomologist, Schøyen and Jørstad. ${ }^{160}$

The spray plans published in Haven for Danish gardeners to carry out, on their own or in a local spray circle, had the form of a monthly spray plan for each type of plant the family gardeners were likely to grow in their gardens. The plans included four sprays on apples and three on pears, plums, cherries, gooseberries, black currants and red currants. One of these yearly sprays should be done with a DDT product and one with a thiophosphoric product like parathion, for instance Bladan or Midd-Tio. Soon the rest of their kitchen garden and decorative plants were included in the plans too. ${ }^{161}$ If a gardening family had a combined kitchen, fruit and decorative garden, like many Danish gardening families did, for instance a colony garden, an allotment garden, a villa garden or a farmhouse garden, the spray plan just for the month of June 1952 prescribed 32 different chemical sprays for different species of garden plants and for different fungi or pest problems in the garden. Only three of the measures prescribed were mechanical, like cutting the sick stems or removing the sick leaves or the plant. However, gardeners were sometimes advised to use the same chemical for different plant cultures in the same month, so they might spray their apples, gooseberries, cabbage and carrots with the same chemical mixture in one spray session. These new plans prescribed far more chemicals, much stronger products and more numerous sprayings than in Weber's plans from the late 1940s. This was now the norm.

\section{Conclusion}

The Scandinavian gardening associations were strong advocates of excessive chemical spraying in the years from 1945 to 1952 . National gardening organisations pushed and fortified the knowledge, methods, procedures and mind-sets of post-war pesticide technologies into broad segments of Scandinavian society and made pesticide technologies "the way we do things around here."

The details of the plant protection experts' advice have clear differences between 1945 and 1952. In 1945, 1946 and 1947 the Norwegian experts in Hagetidend were far more enthusiastic about new chemicals and attempted to dictate the number of sprayings a home gardener should carry out, and the magazine also rejected critical and moderate voices in their

\footnotetext{
159 See for example "Communication number 315 from Statens Forsøgsvirksomhed i Plantekultur," $H A$ (1951), 6ff.

${ }^{160} H A$ (1952), 109.

${ }^{161}$ See for instance the spray plans for April, May, June and July-August, printed in the respective issues of $H A$ (1952 and 1953).
} 
columns. Swedish and Danish expert advice to family gardeners relied for a longer time on older chemicals and was more critical of the ambitious promises made by the producers and sellers of the most popular new synthetic pesticides, claiming they were the final solution to all pest and fungi problems in the home garden. Some Danish plant pathologist even warned that DDT, used wrongly, could even worsen an insect attack because the chemical killed useful predators and caused immunity among the target insects. Nonetheless, the Danish and Swedish experts still recommended almost as many pesticide spraying as did the Norwegians, but with a broader variety of products through the season. The Danish magazine and the Danish experts also took care to remind family gardeners that pesticides and other garden chemicals were poisonous, and some of them extremely lethal. However, the solution was not to refrain from spraying, but to take care and follow instructions when using them.

By 1952, the instructions given to Swedish and the Danish family gardeners were almost in line with those given to Norwegian gardeners. The gardening associations, their experts and editors seem almost overrun by the massive campaigns by the pesticide producers and sellers. The pressure on the Scandinavian gardeners who opened a gardening magazine or joined a local club of their gardening association after 1950 must have been overwhelming and the message was unanimous: a conscientious and ambitious gardener was a person with a close affinity to poison.

\section{Competing interests}

The author has declared that no competing interests exist.

\section{Funding}

Funded within the author's position as professor at the University of Agder. 